\title{
KÁSZEM SZOLEJMÁNI CÉLZOTT LIKVIDÁLÁSA: ESETTANULMÁNY A JUS AD BELLUM LENCSÉJÉN KERESZTÜL
}

https://doi.org/10.51783/ajt.2021.4.02

Az Egyesült Államok 2020. január 3-án, helyi idő szerint hajnalban likvidálta Kászem Szolejmáni iráni tábornokot, amit önvédelmi jogának gyakorlásaként kívánt igazolni. Az elemzésben ezt a „hagyományos”, nem állami szereplőkhöz kapcsolódó célzott likvidálási akcióktól eltérö, egy állam katonai tisztviselője ellen végrehajtott müveletet a jus contra bellum rendszerén keresztül vizsgáljuk, különös figyelmet fordítva a támadás elözményeire, valamint az Egyesült Államok jogi érvelésére és a nemzetközi közösség reakcióira. Az esettanulmány kritikai módszerrel elemzi az Egyesült Államok önvédelmi jogának gyakorlását alátámasztó állításait, különösen azok lex lata megalapozottságát. A tanulmány konklúziója az, hogy Szolejmáni tábornok célzott likvidálása a jus ad bellum rendszere szempontjából kétségkívül jogellenesnek minősült, ugyanis az Egyesült Államok a müveletet megelözően nem volt fegyveres támadás áldozata.

\section{BEVEZETŐ GONDOLATOK}

2020. január 3-án, helyi idő szerint hajnali egy óra előtt Kászem Szolejmáni - az iráni Forradalmi Gárda tábornoka és Irán egyik legbefolyásosabb külpolitikai stratégája - egy repülőgéppel szállt le a bagdadi Nemzetközi Repülőtéren. Negyedórával azt követően, hogy a tábornok leszállt Irakban, autóba ült, és Bagdad belvárosa felé vette az irányt. Ekkor egy amerikai felfegyverzett pilóta nélküli repülőgép emelkedett a Szolejmánit szállító konvoj fölé és három rakétát indított irányába. A légicsapás eredményeképp tíz személy - köztük Szolejmáni tábornok - vesztette életét. ${ }^{1} \mathrm{Az}$

\footnotetext{
* Tanársegéd, PTE ÁJK, 7622 Pécs, 48-as tér 1. E-mail: kis.kelemen.bence@ajk.pte.hu. A tanulmány szerzőre eső része az Innovációs és Technológiai Minisztérium ÚNKP-20-3-II kódszámú Új Nemzeti Kiválóság Programjának a Nemzeti Kutatási, Fejlesztési és Innovációs Alapból finanszírozott szakmai támogatásával készült.

** Hallgató, PTE ÁJK, 7622 Pécs, 48-as tér 1. E-mail: kiss.matyas@pte.hu. A tanulmány részben épít a nevezett szerző „Az Egyesült Államok és Irán 2020-as katonai akciónak nemzetközi jogi megítélése az erőszak alkalmazását kivételesen lehetővé tevő jogalapok szempontjából” címü különdijat nyert OTDK-dolgozatára.

1 Suadad AL-SaLhY: „Tracked, targeted, killed: Quassam Soleimani’s final hours” Middle East Eye 2020. január 4. middleeasteye.net/news/tracked-targeted-killed-qassem-soleimanis-final-hours. Use of armed drones for targeted killings, 15 August 2020, U.N. Doc. A/HRC/44/38 (2020) Annex para. 3.
} 
Amerikai Egyesült Államok (a továbbiakban: USA) ezzel olyan katonai akciót hajtott végre, amelyre nem volt példa egészen a második világháború óta, nevezetesen, hogy célzottan likvidált egy másik államhoz tartozó, „ellenséges” katonai vezetőt. ${ }^{2}$

A célzott likvidálások alatt a nemzetközi jog alanyai (elsősorban államok) által szándékosan, célzatosan és előre megfontoltan végrehajtott műveleteket értünk, amelyek célja egy egyénileg meghatározott személy megölése, mégpedig olyan módon, hogy ez utóbbi nincs az erőszakot alkalmazó őrizetében. ${ }^{3}$ Az elmúlt két évtizedben ezek az akciók már állami policy-kká nőtték ki magukat, azonban egy lényeges pontban eltérnek Szoljemáni tábornok megölésétől, nevezetesen, hogy nem állami szereplőkkel szemben, főként terrorszervezetek tagjai ellen alkalmazták öket. ${ }^{4}$ Ennek fényében annak ellenére is fontos és szükséges ennek a „régi-új” állami gyakorlatnak az elemzése, hogy a célzott likvidálásokról számtalan monográfia és tanulmány született már. ${ }^{5}$

Az esettanulmányban ennek megfelelően Szolejmáni tábornok célzott likvidálását vizsgáljuk a nemzetközi jog lencséjén keresztül. Elsőként röviden bemutatjuk a tényállást a hozzá tartozó szűk értelemben vett előzményekkel, illetve az azt követő állami reakciókkal (2. rész). Ezt követően elemezzük a kérdéses célzott likvidálást

2 Legutóbb 1943 áprilisában hajtottak végre hasonló akciót, amikor lelőtték Jamamoto Iszoroku, a Japán Birodalom admirálisa gépét. Ld. Roland Отто: Targeted Killings and International Law (London, New York: Springer 2012) 8-9. Az eset jelentőségét Anthony Dworkin szerint az mutatja, hogy arra nem egy már meglévő fegyveres konfliktus keretei között került sor, mint a II. világháború idején, hanem egy olyan időszakban, amikor nem volt hagyományos értelemben vett ellenségeskedés a két fél között. Ld. Anthony Dworkin: „Soleimani Strike Marks a Novel Shift in Targeted Killing, Dangerous to the Global Order" Just Security 2020. január 7. justsecurity.org/67937/soleimani-strike-marks-a-novel-shift-in-targeted-killing-dangerous-to-the-global-order/. Ez az állítás azonban nem feltétlenül állja meg a helyét, ugyanis az esetet megelőző incidensek és az arra adott válaszokból esetlegesen arra következtethetünk, hogy már a kérdéses célzott likvidálás idején is fegyveres konfliktus volt Irán és az Egyesült Államok között. E cikk keretein belül azonban ezekkel a kérdésekkel terjedelmi korlátok miatt nem foglalkozunk.

3 Nils Melzer: Targeted Killing in International Law (Oxford: OUP 2008) 5. 10.1093/ law/9780199577903.001.0001. Természetesen más fogalmak is ismertek, ld. pl. Report of the Sepcial Rapporteur on extrajudicial, summary or abitrary executins, Philip Alston, Addendum, Study on Targeted Killings, 28 May 2010. U.N. Doc. A/HRC/14/24/Add. 6. para vagy Oтто (2. lj.) 13.

4 Izrael volt az első állam, amely állami politikaként alkalmazta a célzott likvidálásokat Ld. R. Steven DAviD: „Israel's Policy of Targeted Killing” Ethics \& International Affairs 2003/1. 111. Ehhez később csatlakozott az Egyesült Államok, valamint az Egyesült Királyság is. Ld. obamawhitehouse.archives.gov/the-press-office/2013/05/23/remarks-president-national-defense-university és Louisa Brook-Holland: „Overview of military drones used by the UK armed forces” Briefing Paper 2015/06493. Erre a jellemzőre rámutat például Boris Kondoch is. Ld. Boris KondocH: „The Killing of General Quassem Soleimani: Legal and Policy Issues” Journal of East Asia and International Law 2020. 426.

5 Ld. pl. Magyarországon Kis Kelemen Bence: „Gondolatok a jus ad bellum köréből a célzott likvidálás tükrében” Közjogi Szemle 2017/3. 76-83. vagy SPITzER Jenő: Önvédelem versus terrorizmus - Az erőszak tilalma és az önvédelem joga a nemzetközi jogban, különös tekintettel az Iszlám Állam elleni nemzetközi fellépés lehetőségeire (Budapest: Magyar Katonai Jogi és Hadijogi Társaság, 2019), külföldön pl. Markus Gunneflo: Targeted Killing - A Legal and Political History. (Cambridge: CUP 2016), David KRETZMER: „Targeted Killing of Suspected Terrorists: Extra-Judicial Executions or Legitimate Means of Self-Defence?” European Journal of International Law 2005. $171-212$. 
a jus contra bellum rendszerén keresztül, azaz arra a kérdésre keressük a választ, hogy a tényállásban leírt dróncsapás megfelelt-e az erőszak alkalmazására vonatkozó nemzetközi jogi elöírásoknak, kitérve különösen az események összeadódásának elméletére, a megelőző önvédelem problémájára, valamint Irak helyzetére a művelet kapcsán. (3. rész). Végezetül pedig levonjuk az elemzés konklúzióit a 2020. januári események jus ad bellum legalitását illetően (4. rész).

Az elemzésnek nem lehet célja a célzott likvidálásokra vonatkozó valamennyi, a jus contra bellum rendszeréhez tartozó norma részletes bemutatása és elemzése, ezért az esettanulmányban a jog általunk helyesnek tartott értelmezését alkalmazzuk a tényállásra, azzal, hogy a lényegesebb szakirodalmi és jogalkalmazásbéli vitákat - azok részletekbe vesző elemzése nélkül - természetesen kiemeljük. Ezen felül azt is ki kell emelni, hogy az akció számos egyéb nemzetközi jogilag releváns kérdést is felvet, különösen a humanitárius nemzetközi jog, illetve az emberi jogok nemzetközi rendszere tükrében, ugyanakkor ezek megfelelő mélységű elemzése túlmutatna az esettanulmány terjedelmi korlátain, így vizsgálódásunkat a jus ad bellum területére szükítjük.

\section{TÉNYÁLLÁS}

\subsection{AZ ELŐZMÉNYEK ÉS CÉLZOTT LIKVIDÁLÁS}

Az Egyesült Államok által végrehajtott támadásra nem előzmények nélkül került sor. Ha meg szeretnénk érteni, hogy az USA miért hajtotta végre ezt a katonai akciót, egészen 2019 nyaráig kell visszatekintenünk, ekkor ugyanis a feszültség fokozatosan nőtt az Egyesült Államok és Irán között. Ennek a kiváltó oka az volt, hogy a Trump-adminisztráció 2018. május 8-án „kiléptette” az Egyesült Államokat az „atomalku” néven elhíresült megállapodásból. ${ }^{6}$ A nyár első jelentősebb eseménye 2019. július 13-án történt, amikor is két, nem amerikai tankert ért vélhetően iráni támadás. ${ }^{7}$ Ezt követően még azonos hónapban az iráni hadsereg lelőtt egy amerikai drónt a Hormuzi-szorosban, amely szintén hozzájárult a feszültség növekedéséhez. ${ }^{8} \mathrm{Az}$ amerikai válasz sem késlekedett sokat: szinte napra pontosan egy hónappal később ezúttal ők lőttek le egy iráni drónt a térségben. ${ }^{9}$ A nyár egyik utolsó számottevő eseménye az volt, amikor is a Forradalmi Gárda alakulatai elfoglaltak egy brit

6 Valki László: „Trump és az iráni atomalku sorsa” in Kis Kelemen Bence - MohaY Ágoston PÁNovics Attila (szerk.): Ünnepi tanulmánykötet Bruhács János 80. születésnapja tiszteletére (Pécs: Pécsi Tudományegyetem Állam- és Jogtudományi Kar 2019) 28.

7 Patrick Wintour - Julian Borger: „Two oil tankers attacked in the Gulf of Oman.” The Guardian 2019. június 13. theguardian.com/world/2019/jun/13/oil-tankers-blasts-reports-gulf-of-omanus-navy.

8 Joshua Berlinger - Mohammed TAwfeeq - Barbara Starr - Shirzad Bozorgmehr - Frederik Pleitgen: „Iran shoots down US drone aircraft, raising tensions further in Strait of Hormuz" CNN 2019. június 21. edition.cnn.com/2019/06/20/middleeast/iran-drone-claim-hnk-intVindex.html.

9 „US Destroyed Iranian drone in Strait of Hormuz, Trump Says” BBC 2019. július 19. bbc.com/news/ world-us-canada-49040415. 
tankert. ${ }^{10}$ Ennek az eseménynek a jelentőségét az adja, hogy a britek személyében az Egyesült Államok egyik legközelebbi szövetségeséröl beszélhetünk.

2019 őszén aztán megindult egy erőszakspirál, amelynek végén elérkezünk a Szolejmáni tábornok elleni dróncsapáshoz. A célzott likvidálás közvetlen előzményei december 27-én kezdődtek, amikor a Kataib Hezbollah nevü - minden bizonynyal Irán által támogatott - szervezethez tartozó fegyveresek támadást indítottak egy amerikai légibázis ellen. Az akcióban egy amerikai állampolgár életét vesztette. ${ }^{11}$ Két nappal később az Egyesült Államok erre válaszul a Kataib Hezbollah támaszpontjait bombázta Irak és Szíria területén. ${ }^{12}$ Az év utolsó napján felhergelt tüntetők megtámadták az Egyesült Államok bagdadi nagykövetségét. Halálos áldozata az eseménynek ugyan nem volt, de a követség épületében anyagi károk keletkeztek. $^{13}$

Ilyen előzményeket követően 2020. január 3-án az Egyesült Államok egy fegyveres, pilóta nélküli repülőgéppel támadást hajtott végre a bagdadi repülőtér közelében tartózkodó Szolejmáni ellen. A támadásban nemcsak a tábornok vesztette életét, hanem meghalt többek között Abu Mahdi al-Muhandisz is, aki az iraki Népi Mozgósítási Erők ${ }^{14}$ nevű félkatonai szervezet parancsnoka volt, továbbá nyolc milicista is életét vesztette. ${ }^{15}$

\subsection{A TÁMADÁS KÖZVETLEN UTÓHATÁSA}

A támadás nemcsak Iránt, hanem a teljes nemzetközi közösséget is megdöbbentette. Irán azonnal „durva megtorlást” ígért az Egyesült Államoknak. ${ }^{16}$ Hámeini ajatollah - az iráni államfő - beszédet intézett az iráni néphez az eseményeket követően, amelyben egyrészt Szolejmáni tábornok érdemeit méltatta, továbbá kemény bosz-

10 „Iran Seizes British tanker in Strait of Hormuz” BBC 2019. július 20. bbc.com/news/uk-49053383.

11 Julian E. BARnes: „American Contractor Killed in Rocket Atack in Iraq” New York Times 2019. december 27. nytimes.com/2019/12/27/us/politics/american-rocket-attack-iraq.html. Az Egyesült Államok 51. cikk szerinti levele, 2020. január 8., s3.documentcloud.org/documents/6609717/Art51-Letter.pdf.

12 Barbara StARR - Kevin Bohn - Ross LevitT: „US Strikes 5 Facilities in Iraq and Syria linked to Iranian-backed militia” CCN 2019. december 29. edition.cnn.com/2019/12/29/politics/us-strikesiran-backed-militia-facilities-in-iraq-syria/index.html.

${ }^{13}$ Falih Hassan - Ben Hubbard - Alissa J. Rubin: „Protesters Attack U.S. Embassy in Iraq, Chanting 'Death to America'” New York Times 2019. december 31. nytimes.com/2019/12/31/world/middleeast/baghdad-protesters-us-embassy.html.

14 A Népi Mozgósítási Erők egy, az Iszlám Állam ellen 2014-ben alakított szervezet, amely milíciákat foglal magában. Ennek a szervezetnek a tagja az Abu Mahdi al-Muhandisz által alapított Kataib Hezbollah, aki később a Népi Mozgósítási Erők vezetője is lett. Ld. Crispin Smith: „United States Killed Iraqi Military Official and Iraqi Military Personnel in the Two Recent Attacks" Just Security 2020. január 5. justsecurity.org/67917/united-states-killed-iraqi-military-official-and-iraqi-military-personnel-in-the-two-recent-attacks/.

15 „Qasem Soleimani: US Kills top Iranian general in Baghdad air strike” BBC 2020. január 3. bbc. com/news/world-middle-east-50979463 A/HRC/44/38 (2020) Annex para. 2.

16 „World reacts to US killing of Iran's Qassem Soleimani in Iraq” Al Jazeera 2020. január 3. aljazeera.com/news/2020/1/3/world-reacts-to-us-killing-of-irans-qassem-soleimani-in-iraq. 
szút ígért. ${ }^{17}$ A következő napokban a nemzetközi közösség feszült figyelemmel várta az iráni választ, tekintettel arra, hogy a perzsa állam napokon keresztül hangzatosabbnál hangzatosabb fenyegetésekkel élt. ${ }^{18} \mathrm{~A}$ válasz végül január 8 -án érkezett meg: iráni rakéták csapódtak be az Egyesült Államok légibázisain Irak területén. A támadásnak halálos áldozata nem volt, de több katona is sérüléseket szenvedett. ${ }^{19}$ Irán az akciót követően úgy érezte, kellően bosszút állt az Egyesült Államokon. „Mint egy arcul csapás” - jellemezte Hámeini ajatollah a támadást. ${ }^{20}$ Donald Trump, az Egyesült Államok akkori elnöke igyekezett megnyugtatni az amerikai közvéleményt. Sajtótájékoztatóján úgy fogalmazott: „Irán le fog állni”, és reményét fejezte ki, hogy a perzsa állam nem fog ennél erősebb katonai választ adni a Szolejmáni elleni akcióra. ${ }^{21}$ Megállapítható tehát, hogy ahhoz képest, milyen heves és indulatos nyilatkozatokat tett Irán, a válaszcsapás mértéke - szerencsére - jóval elmaradt az ígéretekhez képest. Ez esetleg a két fél közötti háttérben lezajlott svájci közvetítésnek is volt köszönhető, amelyet az amerikai fél már közvetlenül a célzott likvidálást követően igénybe vett, és amelyen keresztül mértékletesebb kommunikáció zajlott a felek között. ${ }^{22}$

Az iráni válaszcsapás nemzetközi jogi megítélése viszonylag egyszerü, legalábbis ami annak jus ad bellum elemzését illeti, a támadás ugyanis egyértelműen szembemegy az erőszak tilalmával az Egyesült Államok és Irak vonatkozásában. Irán a Biztonsági Tanácshoz intézett levelében saját katonai akcióját „kimértnek” és arányosnak nevezte, amely közvetlen válasz volt a Szoljemáni tábornok elleni célzott likvidálásra. ${ }^{23}$ Marko Milanovic azonban helyesen állapította meg ezzel kapcsolatban, hogy még akkor is, ha elfogadjuk, hogy az erőszak USA általi alkalmazása

${ }^{17}$ Lásd: https://sites.google.com/site/geopoliticsandwars/home/iran-leader-vows-harsh-revengefollowing-assassination-of-gen-soleimani.

18 Nemzetközi jogi értelemben természetesen már az erőszakkal való fenyegetés is jogellenes magatartásnak minősül, feltéve persze, hogy az erőszak alkalmazása a kérdéses helyzetben szintén jogellenes lenne. Ld. ENSZ Alapokmány, 2. cikk (4) bek. Kihirdette: 1956. évi I. törvény az Egyesült Nemzetek Alapokmányának törvénybe iktatásáról (a továbbiakban: ENSZ Alapokmány) Stuart CASEy-Maslen: Jus ad Bellum - The Law on Inter-State Use of Force. (Oxford, London, New York, New Delhi, Sydney: Hart 2020) 37. A fenyegetés iráni részről a legmagasabb szinten jelent meg. Az iráni külügyminisztérium közölte Roháni elnök üzenetét, amiben elítélte a támadást, és bosszúval fenyegette meg az Egyesült Államokat. en.mfa.ir/portaVnewsview/570647(2020. január 3.) Az iráni elnök egy másik nyilatkozatában pedig úgy fogalmazott: „kemény bosszú vár azokra, akiknek Szolejmáni tábornok vére tapod a kezükhöz”. W. J. Hennigan - Kimberly DoziER - John WalcotT: „Iran Has Vowed Revenge Against the U.S. for Killing Qasem Soleimani. Here's What May Happen Next” Time 2020. január 3. time.com/5758750/iran-us-qasem-soleimani.

19 Michael SAFI - Oliver Holmes - Ghaith ABdUL-AHAD: „Iran launches missiles at Iraq airbases hosting US and coalition troops” The Guardian 2020. január 8. theguardian.com/world/2020/jan/08/ suleimani-assassination-two-us-airbases-in-iraq-hit-by-missiles-in-retaliation.

20 „Khamenei: Iran gave U.S. 'slap on face', calls missile strikes 'day of God” Reuters 2020. január 8. reuters.com/article/us-iran-khamenei-usa-slap-idUSKBN1ZGOVV.

21 „Trump: Iran ‘standing down’ after missile strikes” BBC 2020. január 9. bbc.com/news/world-uscanada-51039520.

22 „Report: Swiss back channel helped defuse US-Iran tensions after Soleimani strike” The Times of Israel 2020. január 11. timesofisrael.com/report-swiss-back-channel-helped-defuse-us-iran-tensions-after-soleimani-strike/.

${ }^{23}$ Irán 51. cikk szerinti levele, 2020. január 8. pbs.twimg.com/media/ENzf2JzXOAABPCD.png. 
fegyveres támadásnak minősült, akkor sem tekinthető jogszerűnek az iráni válasz, tekintve, hogy a támadás a válaszcsapás idején már véget ért, az iráni válasz így egyértelműen megtorló jellegű volt. ${ }^{24} \mathrm{~A}$ humanitárius nemzetközi jog tekintetében viszont annak katonai célpont elleni bevetése és a járulékos veszteség hiánya valószínűsíthetően jogszerű bevetésre utal. ${ }^{25}$

Természetesen az iráni válaszcsapás esetében is lehetséges lenne a mélyreható elemzés, annak azonban az eredeti célzott likvidálás szempontjából nincs jelentősége.

\subsection{A NEMZETKÖZI KÖZÖSSÉG REAKCIÓJA}

A csapást és a válaszcsapást követően a világ vezetői szinte egyhangúan önmérsékletre intették a feleket, valamennyi nagyhatalom igyekezett elkerülni a konfliktus súlyosbodását.

Három nappal a Szolejmáni tábornok elleni támadást követően Franciaország, Németország és az Egyesült Királyság közös nyilatkozatban szólították fel a feleket arra, hogy kerüljék az összeütközés további eszkalációját. Iránt továbbá külön is figyelmeztették arra, hogy ne torolja meg a Szolejmáni tábornok elleni légicsapást. ${ }^{26}$ A nyilatkozat azért is érdekes, mert az Egyesült Államok talán legközelebbi szövetségeseiről beszélünk, ennek ellenére az említett országok nem álltak ki egyértelműen az USA mellett.

Oroszország külügyminisztere, Szergej Lavrov, a támadás napján telefonon beszélt akkori amerikai kollégájával, Mike Pompeóval. Az orosz külügyminisztérium közleménye szerint Lavrov hangsúlyozta, hogy az ilyen akciók durván sértik a nemzetközi jogot, és elítélendők. Az orosz külügyminiszter rámutatott, hogy ez a cselekmény súlyos hatással lehet a Közel-Kelet regionális békéjére és stabilitására. ${ }^{27}$ A kínai külügyminisztérium szóvivője január 3-án a napi sajtótájékoztató keretében több kérdés vonatkozásában is érintette a Szolejmáni tábornok elleni támadást. Az egyik kérdésre válaszul elmondta: „[e]llenezzük az erőszak önkényes alkalmazását, és az azzal való fenyegetést is. Arra kérjük a feleket - különösen az amerikaiakat - maradjanak nyugodtak, visszafogottak, és kerüljék a feszültség további fokozását." ${ }^{8}$ „Alapvető fontosságú, hogy a helyzet ne eszkalálódjon tovább” - áll a pár soros indiai kommünikében, amelyet az indiai külügyminisztérium weboldalán

${ }^{24}$ Marko Milanovic: „Iran Unlawfully Retaliates Against the United States, Violating Iraqi Sovereignty in the Process" EJIL:Talk! 2020. január 8. ejiltalk.org/iran-unlawfully-retaliates-against-theunited-states-violating-iraqi-sovereignty-in-the-process/.

${ }^{25}$ Uo.

${ }^{26}$ Lásd: basedoc.diplomatie.gouv.fr/vues/Kiosque/FranceDiplomatie/kiosque.php?fichier=baen2020-01-06.html\& fbclid=IwAR31ACVOoIg8vFfBt7S6uScbav19iaKOGOT I9X03yW17bZF5wBpOro60t0\#Chapitre2.

${ }^{27}$ Lásd: mid.ru/en/telefonnye-razgovory-ministra//asset_publisher/KLX3tiYzsCLY/content/idV 3989636? fbclid=IwAR1MIayIU5RBCzlfD5opHmRvEPtSrLtQ_56d1bJ-Y1BvB6lb4aav4P3yBXg.

${ }^{28}$ Lásd: fmprc.gov.cn/mfa_eng/xwfw_665399/s2510_665401/2511_665403/t1729508.shtml. 
jelentettek meg a támadást követően. ${ }^{29}$ A semleges és elítélő nyilatkozatok mellett azonban olyan államok is voltak, amelyek pozitívan nyilatkoztak az akció kapcsán. Brazília $^{30}$ és Izrael ${ }^{31}$ például támogatták az Egyesült Államok akcióját.

Érdemes megjegyezni, hogy nemcsak egyes államok, hanem különböző nemzetközi szervezetek is megszólaltak az akció kapcsán. Charles Michel, az Európai Tanács elnöke is kiadott egy nyilatkozatot nem sokkal az amerikai támadást követően. Számos vezetőhöz hasonlóan felszólította a feleket az erőszak megfékezésére: „[a]z erőszak, a provokációk és a megtorlások ciklusát, amelynek tanúi lehetünk Irakban, meg kell állítani." ${ }^{32}$ Az eset kapcsán az ENSZ is kiadott egy közleményt. „Ez egy olyan pillanat, amikor a világ vezetőinek maximális visszafogottságot kell tanúsítaniuk." - mondta Antonio Guterres, a világszervezet főtitkára. ${ }^{33}$

Irak szerepe egészen egyedülálló volt az eseménysorozatban. Nemcsak a Szolejmáni elleni támadás, de az azt közvetlenül megelőző konfrontációk is szintén ott játszódtak le. Irak január 6-án küldött levelet az ENSZ Biztonsági Tanácsának a célzott likvidálást követően, amelyben élesen elítélte a támadást. A levél úgy fogalmaz, hogy „elkötelezettek vagyunk amellett, hogy Irak területét nem lehet a szomszédos államok elleni mủveletek helyszíneként használni”. ${ }^{34}$ Hozzáteszi, hogy az iraki kormány provokatívnak és ellenségesnek tekinti azokat a katonai akciókat, amelyeket a kormány beleegyezése nélkül hajtanak végre a területükön. A konkrét akciót pedig agressziónak tekintik, amely súlyos megsértését jelenti annak a megállapodásnak, amely alapján az Egyesült Államok az országban állomásozik. ${ }^{35}$ Irak ezen felül parlamenti határozatban szólította fel az USA-t, hogy vonja ki csapatait az országból, amelynek utóbbi természetesen nem tett eleget. ${ }^{36}$

A nemzetközi közösség más tagjai is véleményt nyilvánítottak Szolejmáni tábornok célzott likvidálásáról. A véleményeket egy adatbázisba gyüjtöttünk össze, amely a tanulmány végén olvasható. ${ }^{37} \mathrm{~A}$ vizsgálat eredményét összefoglalóan a következő ábra szemlélteti:

${ }^{29}$ Lásd: mea.gov.in/press-releases.htm?dtl\%2F32251\%2FKilling_of_a_senior_Iranian_leader_by_ the_US\&fbclid=IwAR3kLVNK9Y9_L7TjGYxL72O7ov2c1OwCiwZC3q_nuM6fS2ft1cWt-fmg8Hs.

30 „Iran summons Brazil's charge d'affaires in Tehran after Soleimani comments” Reuters 2020. január 7. reuters.com/article/us-iraq-security-iran-braziViran-summons-brazils-charge-daffairesin-tehran-after-soleimani-comments-idUSKBN1Z61IF?feedType $=$ RSS\&.

31 Mehrnusch ANSSARI - Benjamin NubBerger: „Compilation of States Reactions to U.S. and Iranian uses of force in Iraq in January 2020" Just Security 2020. január 22. justsecurity.org/68173/compilation-of-states-reactions-to-u-s-and-iranian-uses-of-force-in-iraq-in-january-2020\%.

32 Lásd: consilium.europa.eu/en/press/press-releases/2020/01/03/statement-by-charles-michel-president-of-the-european-council-on-the-situation-in-iraq ?fbclid=IwAR3DufOyWO8HMAhNKzTuEDYglKdLtftQpexdDM59lDjLEEVbl4QKbRmJu3o.

${ }^{33}$ Lásd: news.un.org/en/story/2020/01/1054701.

${ }^{34}$ Identical letters dated 6 January 2020 from the Permanent Representative of Iraq to the United Nations addressed to the President of the Security Council, 6 January 2020. U.N. Doc. S/2020/15. 35 Uo.

36 „U.S. Drone Strike in Iraq Kills Iranian Military Leader Qasem Soleimani” The American Journal of International Law 2020. 320.

${ }^{37} \mathrm{Az}$ adatbázis elkészítésében saját kutatásunk mellett nagyban segítségünkre volt Mehrnusch Anssari és Benjamin Nußberger munkája. Ld. ANSSARI - NußBERGER (31. lj.). 
1. sz. ábra: Szolejmáni célzott likvidálására adott állami reakciók ${ }^{38}$

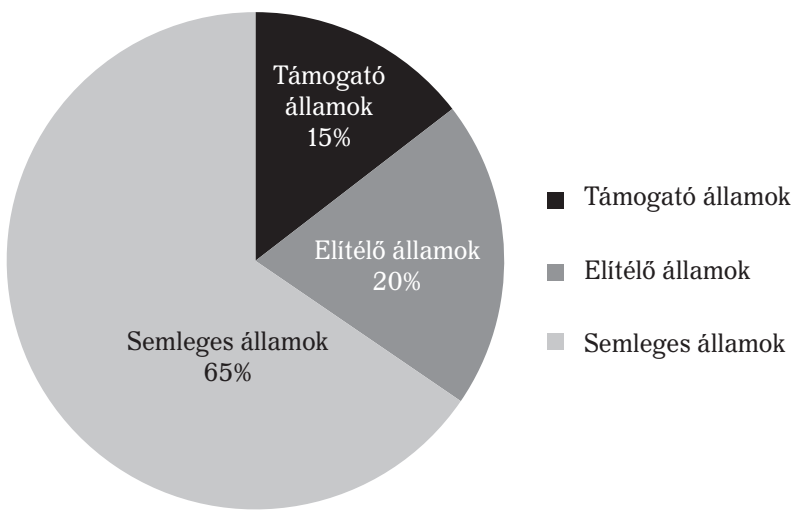

E nyilatkozatok álláspontunk szerint ékes példái annak, hogy az államok a legtöbb esetben nem fogalmazzák meg egyértelműen véleményüket egy, a nemzetközi közösségben zajló esemény nemzetközi jogi értelemben vett jogszerűségét vagy jogellenességét illetően, hanem inkább a saját jövőbeni mozgásterük növelése érdekében egyfajta „konstruktív kétértelműséghez” ${ }^{39}$ folyamodnak. Ebből következően érdemben nem lehetséges rájuk támaszkodni a legalitás megítélése kapcsán.

\section{A TÉNYÁLLÁS JOGI ÉRTÉKELÉSE}

\subsection{AZ EGYESÜLT ÁLLAMOK JOGI VÉLEMÉNYE A TÁMADÁS JOGSZERŰSÉGÉVEL KAPCSOLATBAN}

Az Egyesült Államok a támadás kapcsán több tekintetben is állást foglalt az akció jogszerűsége mellett. Egyfelől teljesítve - az azonnali értesítés előírását elég liberálisan értelmezve - az ENSZ Alapokmány 51. cikkéből folyó eljárásjogi kötelezettségét, 2020. január 8-án tájékoztatta a Biztonsági Tanácsot önvédelmi cselekményéről. ${ }^{40}$ Ebben a levélben az USA önvédelmi jogára hivatkozott a célzott likvidálás jus

${ }^{38} \mathrm{Az}$ ábrán összesen ötvenöt állam és nemzetközi szervezet állásfoglalását mutatjuk be. Ezek közül harminchatot helyeztünk a semleges, míg nyolcat a támogató, tizenegyet pedig az elítélő kategóriába.

${ }^{39}$ Dapo Akande - Marko Milanovic: „The Constructive Ambiguity of the Security Council's ISIS Resolution" EJIL:Talk! 2015. november 21. ejiltalk.org/the-constructive-ambiguity-of-thesecurity-councils-isis-resolution. Ennek egyik iskolapéldája az ENSZ BT. 2249. (2015) sz. határozata. Ld. Marko Milanovic: „Accounting for the Complexity of the Law Applicable to Modern Armed Conflicts" in Christopher M. ForD - Winston S. Williams (szerk.): Complex Battlespaces - The Law of Armed Conflict and the Dynamics of Modern Warfare. (Oxford: OUP 2019) 45. Security Council Resolution 2249 (2015) S/RES/2249 (2015) 2015. november 20.

${ }^{40} \mathrm{Az}$ Egyesült Államok 51. cikk szerinti levele. 
ad bellum jogszerűségének indokolása céljából. Bár maga a levél nem nevezi meg, hogy az Egyesült Államok az egyéni vagy kollektív önvédelem jogát gyakorolta, egy, a támadás kapcsán kiadott jogi és politikai állásfoglalás - amely főként belső amerikai jogi kérdésekkel foglalkozik - ezt pontosítva „nemzeti” önvédelemről beszél, amely kétséget kizáróan az egyéni önvédelem kategóriáját jelöli. ${ }^{41}$

Az USA álláspontja szerint az önvédelmi akcióra az Egyesült Államok haderejét és érdekeltségeit ért, eszkalálódó fegyveres támadások sorozata adott okot, amelyre válaszul Irán elrettentése, valamint a jövőbeni támadások megakadályozásának céljából került sor. ${ }^{42}$ Az 51. cikk szerinti levélből kitűnik, hogy az Egyesült Államok nemcsak fokozódó fegyveres támadások, hanem fenyegetések sorozatának áldozata is volt. Ilyennek volt tekinthető a USS BOXER nevü hajóra jelentett fenyegetés egy iráni drón által 2019 nyarán. ${ }^{43}$ A fegyveres támadások sorozata szintén ekkor, 2019 nyarán kezdődött, amikor egy iráni rakéta megsemmisített egy amerikai felderítő drónt a Hormuzi-szorosban. ${ }^{44}$ A levél ezen felül megemlít még kereskedelmi hajók elleni támadásokat, valamint Szaúd-Arábia elleni rakéta- és dróntámadásokat is. ${ }^{45}$

Az USA ezt követően több más támadás felsorolásával folytatta 51. cikk szerinti levelét, nevezetesen azzal, hogy az ún. Kudsz Erők támogatta iraki militáns csoportok - például a Kataib Hezbollah - lőttek közvetetten iraki amerikai katonai bázisokat 2019 december végén, amelyre néhány nappal később az Egyesült Államok már fegyveresen válaszolt. Ezt követően pedig a bagdadi amerikai nagykövetséget is támadás érte azonos csoportok által 2019 utolsó napján, amely jelentős anyagi károkat okozott a nagykövetség ingatlanában. ${ }^{46} \mathrm{~A}$ jogi és politikai állásfoglalás alapján pedig az is egyértelmű, hogy bár az Egyesült Államok úgy tekintette, hogy a további támadások bekövetkezésének esélye fennáll, de az önvédelmi cselekményt már a korábbi sorozatos támadások is megalapozták. ${ }^{47}$

\subsection{A CÉLZOTT LIKVIDÁLÁS JUS AD BELLUM ÉRTÉKELÉSE}

Elsőként fontos leszögezni, hogy a fenti tényállás alapjául szolgáló célzott likvidálást kizárólag az Egyesült Államok által kifejezett jogi álláspont tükrében lehetséges felülvizsgálni. Ez a Nemzetközi Bíróság Nicaragua ügyben hozott döntéséből fakad, amelyben a hágai testület kimondta, hogy nem tudhatunk be az államoknak olyan jogi meggyőződést vagy véleményt, amelyet saját maguk nem fogalmaznak

${ }^{41}$ Notice on the Legal and Policy Frameworks Guiding the United States' Use of Military Force and Related National Security Operations (a továbbiakban: USA állásfoglalás) 2. justsecurity.org/wpcontent/uploads/2020/02/notice-on-the-legal-and-policy-frameworks-guiding-the-united-states-use-of-military-force-and-related-national-security-operations.pdf.

${ }^{42} \mathrm{Az}$ Egyesült Államok 51. cikk szerinti levele 1. és USA állásfoglalás 1.

${ }^{43} \mathrm{Az}$ Egyesült Államok 51. cikk szerinti levele 1.

44 Uo.

45 Uo.

${ }^{46}$ Az Egyesült Államok 51. cikk szerinti levele 1-2.

47 USA állásfoglalás 2. 
meg. ${ }^{48}$ Ebből adódóan tehát a következőkben az USA nemzetközi jogi érvelése mentén vizsgáljuk felül az ott kifejezett jogi álláspontot az ismert tények alapján, így tehát nem értelmezzük a tisztán politikai vagy belső jogi jellegű megnyilvánulásokat. ${ }^{49}$ A tényállást - a fentiek szerint - az erőszak alkalmazására vonatkozó nemzetközi jogi normák, azaz a jus ad bellum lencséjén keresztül elemezzük.

A támadást követően a Trump-kormányzat elsőként a Szolejmáni által szervezett, küszöbön álló támadásokra hivatkozott, ${ }^{50}$ így egyfajta megelőző önvédelmi helyzetet vízionált talán a korábban bekövetkezett támadásokra való válasz helyett. ${ }^{51} \mathrm{Az}$ ENSZ Biztonsági Tanácsának küldött levélben, illetve az azt követő jogilag releváns nyilatkozatokban viszont inkább a fokozódó korábbi támadások álltak a középpontban. ${ }^{52}$ Tekintve, hogy az Egyesült Államok nyilvánvalóan az 51. cikk szerinti levelet szánta a nemzetközi jogilag legrelevánsabb érveket tartalmazó dokumentumnak, így elsőként a támadások összeadódásának problémájával foglalkozunk, majd rátérünk a megelőző önvédelem kérdéskörére.

\subsubsection{AZ ESEMÉNYEK ÖSSZEADÓDÁSA}

Az USA 51. cikk szerinti levelében több korábbi fenyegetésröl, valamint fegyveres támadásról és egyszerủ támadásokról tesz említést. Ilyenek voltak például a 2019 júliusi amerikai megfigyelő drón lelövése, valamint a Kataib Hezbollah nem állami szereplő - és más csoportok - által elkövetett sorozatos támadások 2019 második felében, amelyek az Egyesült Államok szerint alátámasztja az önvédelem alkalmazásának lehetőségét. Ezek közül kiemelést érdemel a 2019. december 27-ei támadás, amelyben egy amerikai személy vesztette életét. Erre még azonos napon az USA fegyveres választ is adott. Ezt követően december 31-én az Egyesült Államok bagdadi nagykövetségét is támadás érte azonos csoportok részéről, amelyben azonban anyagi káron kívül személyi sérülés nem következett be. ${ }^{53}$ A szükszavú amerikai nyilatkozatot kiegészíthetjük azzal, hogy egyes szerzők 2019 szeptembere óta tizennégy támadásról tesznek említést. ${ }^{54}$ Az Egyesült Államok jogi álláspontja szerint

${ }^{48}$ Military and Paramilitary Activities in and against Nicaragua (Nicaragua v. United States of America), Merits, Judgment, I.C.J. Reports 1986, p. 14. (a továbbiakban: Nicaragua ügy) para. 266.

${ }^{49}$ Uo. Ez álláspontunk szerint azonban bővebb annál, amit az USA az 51. cikk szerinti levelében közzétett és benne foglaltatik minden jogilag releváns, jogi meggyőződést kifejező állami nyilatkozat. Vö. Kondoch (4. lj.) 429.

${ }^{50}$ Lásd: c-span.org/video/?467859-1/president-trump-speaks-air-strike-killed-iranian-commander. A támadások tervezése más megnyilvánulásban is megjelent, ahol az elrettentés játszott hangsúlyos szerepet. Lásd: defense.gov/Newsroom/Releases/Release/Article/2049534/statement-bythe-department-of-defense/.

51 (36. lj.) 315.

52 Az Egyesült Államok 51. cikk szerinti levele és USA állásfoglalás.

${ }^{53}$ Az Egyesült Államok 51. cikk szerinti levele 1-2.

54 Stefan TAlmon - Miriam Heipertz: „The U.S. killing of Iranian General Qasem Soleimani: of wrong trees and red herrings, and why the killing may be lawful after all" Bonn Research Papers on Public International Law 2020/18. 2., https://doi.org/10.2139/ssrn.3530273. 
a támadások e sorozata elégségesen alátámasztja az önvédelmi jog alkalmazási lehetőségét. ${ }^{55}$

Ezt az érvelést nem lehet elutasítani további vizsgálat nélkül, ugyanis a nemzetközi jogirodalomban létezik egy ún. „összeadódási elmélet” (accumulation of events, Nadelstichtaktik), amelynek alapján egyfelöl ha egy meghatározott állam elleni támadás nem is éri el a fegyveres támadás szintjét, de az egy eseménysorozat részének tekinthető, akkor ez lehetőséget ad a fegyveres támadás mennyiségi minimumfeltétének átlépésére, másképpen a kisebb intenzitású sorozatos támadások együttesen, mintegy „összeadódva” válnak az önvédelmi jogot aktiváló fegyveres támadássá. ${ }^{56}$ Másfelől e teória még abból a szempontból is jelentős, hogy vele az arányossági teszt is lazítható, ugyanis arányaiban nagyobb szabású önvédelmi akcióra is lehetőséget adna sorozatos támadások esetén, mint amilyenre egy izolált fegyveres támadás lehetőséget biztosítana. ${ }^{57}$

Az elmélet támogatottságát jelzi, hogy a Nemzetközi Bíróság már több esetben tett említést arról, hogy hasonló tényállás esetén esetleg lehetséges az önvédelemre való hivatkozás. Például a Nicaragua ügyben három évet felölelő, határon átnyúló incidensek esetén mondta ki azt a Bíróság, hogy mivel nem áll rendelkezésre elégséges információ ezekről a betörésekről, így nem lehet megállapítani, hogy azok önmagukban vagy együttesen fegyveres támadásnak minősülnek-e. ${ }^{58}$ Az Olajfúrótornyok ügyben a hágai testületnek egy kísértetiesen hasonló ügyben kellett véleményt nyilvánítania az Egyesült Államok és Irán konfliktusában. Ebben az ügyben a Nemzetközi Bíróság úgy határozott, hogy egy amerikai hajóra kilőtt rakéta, valamint egy nem amerikai hajó megtámadása, illetve egy, az eseménysorozathoz nem köthető, vélhetően korábbi aknatelepítés Irán részéről még összeadódva sem tekinthető fegyveres támadásnak. ${ }^{59}$ Végül, de nem utolsósorban a Bíróság a Kongó kontra Uganda ügyben is utalt a kérdésre, mégpedig olyan módon, hogy bár a tényállás alapjául szolgáló támadások akár összeadódva is figyelembe vehetők, azok mégsem tudhatók be a Kongói Demokratikus Köztársaságnak ${ }^{60}$ A hágai bírák összesen négy egymást követő támadásról tettek említést 1998 júniusa és augusztusa között, ${ }^{61}$ ezek tehát azok, amelyeket kumulatíve figyelembe lehetett volna venni.

Tom Ruys részletes elemzésében igyekszik kimutatni azt, hogy a Nemzetközi Bíróság mellett számos állam is sorozatosan hivatkozott az „összeadódási elméletre”, amelyek esetében ugyan a nemzetközi közösség részéről negatív visszajelzé-

55 USA állásfoglalás 2 .

56 Tom RuYs: 'Armed Attack' and Article 51 of the UN Charter. (Cambrdige: CUP 2010) 168.; Noam LuBELl: Extraterritorial Use of Force Against Non-State Acotrs. (Oxford: OUP 2011) 54., https:// doi.org/10.1017/cbo9780511779527.

57 RuYs (56. lj.) 168.

58 Nicaragua ügy para. 231.

${ }^{59}$ Oil Platforms (Islamic Republic of Iran v. United States of America), Judgment, I.C.J. Reports 2003 , p. 161. (a továbbiakban: Olajfúrótornyok ügy) para. 64. A Bíróság az iráni felelősség kérdéskörére e tekintetben nem tért ki.

${ }^{60}$ Armed Activities on the Territory of the Congo (Democratic Republic of the Congo v. Uganda), Judgment, I.C.J. Reports 2005, p. 168. (a továbbiakban: Kongó kontra Uganda ügy) 146. bek.

${ }^{61}$ Kongó kontra Uganda ügy para. 132. 
sek érkeztek, ezek azonban főként a kérdéses katonai akciók egyéb nemzetközi jogi jogellenességére vonatkoztak, például az arányosság elvének megsértésére. ${ }^{62}$ Ebből következően tehát kumulatív karakterü támadások esetén alkalmazhatónak tartja az önvédelem jogát, de csak akkor, ha a sorozatos támadások időben, forrásban és célban kapcsolódnak egymáshoz, továbbá a túl távoli támadásokat sem vehetjük alapul. ${ }^{63}$

Ebből a logikából kiindulva veti fel Stefan Talmon és Miriam Heipertz, hogy a Szolejmáni célzott likvidálását megelőző, az Egyesült Államokat ért támadások esetében az időbeli, forrásbéli és célbéli kapcsolódás megállapítható, és ilyen esetben a soron következő támadásnak nem kell „küszöbön állónak” lennie ahhoz, hogy az önvédelem joga gyakorolható legyen. ${ }^{64}$ Ezzel szemben Agnès Callamard, az ENSZ törvénytelen, gyorsított vagy önkényes kivégzések vizsgálatáért felelős különmegbízottja 2020-as jelentésében úgy foglalt állást, hogy a kérdéses incidensek különállók és jól megkülönböztethetők egymástól, és nem is szükségszerűen fokozódnak, továbbá nem kapcsolódnak sem időben sem célpontjaikban. Mindezeken felül egyetlen folyamatban lévő támadásról sem tett említést az amerikai fél az önvédelmi cselekményével kapcsolatban. ${ }^{65}$

Álláspontunk szerint ezek a kritikák alaptalanok, ugyanis ahogy a Kongó kontra Uganda ügy is világosan jelzi, akár három hónapon át elhúzódó incidensek is képesek „összeadódni”, amely így egyáltalán nem teszi elképzelhetetlenné a 2019 szeptembere és 2019 december vége közötti támadások összeadódását, főként úgy, hogy azok mind a Kataib Hezbollahtól - és más meg nem nevezett szervezetektől - származtak Irak területén belül. Ezen felül az összeadódási elmélet lényege éppen abban áll, hogy az ugyan korábban történt eseményekre alapozott, de megelőző önvédelmi helyzetet teremt, amelyben az adja az önvédelmi cselekmény szükségességét, hogy a jövőben is várhatóak ilyen és ehhez hasonló intenzitású támadások, mintegy a „művelet” részeként. Folyamatban lévő fegyveres támadást elvárni ennek fényében az elmélet alkalmazása esetén nem lehetséges, hacsak a sorozatosan bekövetkező egyes támadásokat nem tekintjük egy egységes, hosszan tartó fegyveres támadásnak. Az ellencsapás szükségességét azonban ebben az esetben is egy egyáltalán nem biztos, jövőbeni újabb támadással való folytatódás lehetősége adja.

Mindezek ellenére - rímelve Noam Lubell (nem a kérdéses célzott likvidálás kapcsán megfogalmazott) álláspontjára - az összeadódási elmélet alkalmazásának igen súlyos problémái vannak. Egyfelől a fegyveres támadások szintjét el nem érő, kisebb intenzitású incidensek nem biztos, hogy akár „összeadódva” olyan fenyegetést jelentenek az államra, amelyre önvédelemmel lenne szükséges reagálni. Mivel ezek a támadások már véget értek, ezért ilyenkor a nemzetközi béke és biztonság fenntartására létrejött ENSZ-rendszer keretén belül, például a Biztonsági Tanácshoz

${ }^{62}$ Ruys (56. lj.) 169-172.

63 Uo. 168. és 175.

${ }^{64}$ TAlmon-Heipertz (54. lj.) 8-10.

${ }^{65}$ A/HRC/44/38. para. 57. Ezt a problémát Adil Ahmad Haque is felvetette. Ld. Adil Ahmad HAQUE: „U.S. Legal Defense of the Soleimani Strike at the United Nations: A Critical Assessment” Just Security 2020. január 10., justsecurity.org/68008/u-s-legal-defense-of-the-soleimani-strikeat-the-united-nations-a-critical-assessment/. 
fordulással szükséges rendezni a kialakulóban lévő konfliktust. Másfelöl a megelőző önvédelem egyfajta közvetett formájának alkalmazása miatt teljesen szembemennénk az ENSZ Alapokmány erőszaktilalmi rendszerével is. ${ }^{66}$ Ezzel gyakorlatilag megkerülhetők az önvédelmi jog garanciális jellegű szabályai, mint a fegyveres támadás mennyiségi követelménye, valamint annak időbeli dimenziója is, ami végső soron egyfajta örökös önvédelmi helyzetet teremt. ${ }^{67}$ Ennek alapján tehát úgy véljük, hogy az összeadódási elmélet alkalmazhatósága alapjaiban inkompatibilis a hatályos jus contra bellum rendszerével, és még akkor sem elfogadható, ha a Nemzetközi Bíróság, illetve az állami gyakorlat egy része így foglal állást.

Abban az esetben azonban, ha a Nemzetközi Bíróság esetjoga és az állami gyakorlat nyomán mégis elfogadnánk azt, hogy kisebb intenzitású cselekmények összeadódva fegyveres támadássá „állnak össze”, akkor sem feledkezhetünk meg a fegyveres támadás minőségi követelményéről, vagyis arról, hogy az önvédelem jogára hivatkozás csak akkor lehetséges, ha a fegyveres támadás betudható egy államnak. ${ }^{68}$ Ez abból a szempontból jelent problémát, hogy a releváns, tehát 2019 szeptembere óta elkövetett támadásokat több fegyveres csoport, köztük a Kataib Hezbollah követte el, amelyek bár az Egyesült Államok szerint Irán támogatásával müködnek, ${ }^{69} \mathrm{a}$ Kataib Hezbollah esetében mégis Irak fegyveres erejének egy részéről beszélünk. ${ }^{70}$

Ezt a kérdést a témával foglalkozó szakirodalom eddig nagyrészt figyelmen kívül hagyta, vagy pedig alapjaiban véve téves következtetéseket vont le ezzel kapcsolatban. ${ }^{71}$ Elsőként le kell szögezni, hogy mivel az Egyesült Államok haderejét megtámadó egyetlen megnevezett fegyveres csoport formális értelemben része az iraki fegyveres erőknek, ezért az USA-t ért támadásokat valójában Irak, egy állami szervén keresztül követte el. ${ }^{72}$ Ebből következően az Egyesült Államoknak az önvédelmi cselekményét is - legalábbis részben - Irak ellen kellett volna megvalósítania. Mint tudjuk, a gyakorlatban ez így is történt, azonban Irakkal kapcsolatban az USA semmilyen nemzetközi jogi érvelést nem tett közzé. ${ }^{73}$

E tekintetben mindenképpen felmerül a probléma, hogy a Kataib Hezbollah Irán utasítására cselekedett-e, ${ }^{74}$ ezzel pedig ultra vires aktust valósított-e meg. Az

${ }^{66}$ LuBELl (56. lj.) 53-54.

67 Kondoch (4. lj.) 430.

${ }^{68}$ Ld. pl. KAJTÁR Gábor: „A nem állami szereplők elleni fegyveres fellépés lehetőségei és problémái” In FARKAS Ádám - VÉGH Károly (szerk.): Új típusú hadviselés a 21. század második évtizedében és azon túl. Intézmények és jogi kihívások. (Budapest: Zrínyi 2020) 94-95.

${ }^{69}$ USA állásfoglalás 2. Az Egyesült Államok 51. cikk szerinti levele 1. A Kataib Hezbollah a The Washington Institute for Near East Policy szerint az Iráni Forradalmi Gárda Kudsz Erők által irányított speciális csoportok egyesüléséből jött létre 2005 és 2007 között, majd az Egyesült Államok 2009-ben terrorszervezetté nyilvánította, és hitelt érdemlően bizonyított, hogy a csoportot az iráni haderő irányítja, valamint részben finanszírozza is. Ld. Michael KNIGHTs - Crispin SmitH - Hamdi MaLIK: „Profile: Kataib Hezbollah” The Washington Institute for Near East Policy 2021. április 1., washingtoninstitute.org/policy-analysis/profile-kataib-hezbollah.

70 SMith (14. lj.).

71 Ld. pl. TALMON-Heipertz (54. lj.) 9.

72 Draft articles on Responsibility of States for Internationally Wrongful Acts, with commentaries, 12 December 2001. U.N. Doc. A/RES/56/83 (2001) (a továbbiakban: ARSIWA) 4. cikk

73 Kondoch (4. lj.) 431.

74 Talmon-Heipertz (54. lj.) 9. A/HRC/44/38. para. 60. 
ARSIWA 7. cikke azonban hatáskörtúllépés vagy utasításnak való ellenszegülés esetében is csak akkor teszi lehetővé a felelősség elkerülését, ha a szervezet nem „hivatalos minőségében” tanúsította a kérdéses magatartást. E tekintetben a kommentár megjegyzi, hogy abban az esetben, ha a magatartás rendszeres vagy visszatérő jellegű, amelyről az államnak tudnia kell, vagy tudnia kellett volna, akkor lépéseket kellett volna tennie a helyzet rendezése érdekében, így a felelősség alól nem tudja kivonni magát. ${ }^{75}$ Bár vitatható, hogy egy vélhetően Irán utasítására cselekvő iraki állami szerv hivatalos minőségében cselekedett-e, a kommentár érvelését (rendszeres, visszatérő jellegű magatartás) felhasználva álláspontunk szerint kétséget kizáróan egy iraki támadássorozatról beszélhetünk. Ezt támasztja alá továbbá az a kommentárban megnevezett humanitárius nemzetközi jogi rendelkezés is, amely a fegyveres erők összes tevékenységét az államnak tudja be. ${ }^{76}$

Stefan Talmon és Miriam Heipertz felvetik, hogy a Kataib Hezbollah esetében egy Irán rendelkezésére bocsátott állami szervről lehet szó, így Iránnak tudható be a fegyveres csoport magatartása. ${ }^{77}$ A szerzők szerint a rendelkezésre bocsátást ebben az esetben maga a Kataib Hezbollah tette meg. ${ }^{78}$ Ez azonban egy olyan abszurd helyzethez vezetne, hogy minden állami szerv önállóan dönthetne arról, hogy mely állam rendelkezéseit követi, és ezáltal mely államnak kellene betudni magatartását. Ez a gyakorlatban ellehetetlenítené még a de jure állami szervek viszonylag egyértelmű betudhatósági helyzetét is. Véleményünk szerint tehát ebben az esetben nem beszélhetünk Irán rendelkezésére bocsátott iraki állami szervről, azt ugyanis Irak más állami szerve tudomásunk szerint nem tette meg.

Mégsem lehet szó nélkül elmenni amellett, hogy milyen jogi következménye lenne annak, ha Irán valóban támogatta a Kataib Hezbollahot, és a fegyveres csoport ténylegesen az állam utasítására cselekedett, ahogy azt az Egyesült Államok is állította. ${ }^{79}$ Tekintve a Kataib Hezbollah iraki állami szerv státuszát, ilyen esetben felmerül a párhuzamos betudhatóság (dual attribution) lehetősége, amelyet a Nemzetközi Jogi Bizottság mind az államfelelősség, mind pedig a nemzetközi szervezetek felelőssége tekintetében elfogadott. ${ }^{80}$ Ebben a szituációban - amikor egy de jure állami szerv egy másik állam irányítása alatt is áll - a párhuzamos betudhatóság egy olyan esetével van dolgunk, amelynél egy csoport magatartása több államnak is betudható. ${ }^{81}$ Ebben az esetben is szükséges azonban egyfajta önmérsékletet tanúsítani, ugyanis az államfelelősség alapú betudás esetében a Nemzetközi Bíróság a

${ }^{75}$ ARSIWA 46. para. (8).

${ }^{76}$ ARSIWA 46. para. (4) és (8). Az 1949. évi genfi egyezmények I. Kiegészítő jegyzőkönyve. Kihirdette: A háború áldozatainak védelmére vonatkozóan Genfben 1949. augusztus 12-én kötött Egyezmények I. és II. kiegészítő Jegyzőkönyvének kihirdetéséről szóló 1989. évi 20. törvényerejű rendelet 91 . cikk.

77 TAlmon-Heipertz (54. lj.) (54. lj.) 14. ARSIWA 6. cikk.

78 TALMON-Heipertz (54. lj.) 14.

79 Az Egyesült Államok 51. cikk szerinti levele 1.

${ }^{80}$ André Nollkaemper - Dov Jacobs: „Shared Responsibility in International Law: A Conceptual Framework” Michigan Journal of International Law 2013/34. 385.

${ }^{81}$ Francesco Messineo: „Attribution of Conduct” in André NollKaemper - Ilias Plakokefalos (szerk.): Principles of Shared Responsibility in International Law - An Appraisal of the State of the Art (Cambridge: CUP 2014) 67. 
Nicaragua ügyben a contrák pénzügyi támogatását, megszervezését, kiképzését, felszerelését, valamint néhány katonai célpontjának kiválasztását és más magatartásokat sem tekintette olyannak, mint amely alapján megállapítható lenne az Egyesült Államok felelőssége. ${ }^{82} \mathrm{Az}$ önvédelem jogának gyakorlása tekintetében azonban egy ennél alacsonyabb szintủ betudási koncepció is elegendő lehet, nevezetesen a küldés vagy „komoly részvétel”. ${ }^{83}$ Ebből kiindulva tehát nem elképzelhetetlen, hogy - az összeadódási elmélet alkalmazása esetén - az Egyesült Államok önvédelmi jogával élve jogszerűen erőszakot alkalmazhatott volna mind Irakkal, mind pedig Iránnal szemben, az USA jogi véleménye azonban a fentieknek megfelelő jogi megalapozást egyáltalán nem feltételez. A küldés vagy „komoly részvétel” betudási megoldás azokkal a nem állami szereplőkkel szemben is alkalmazható lehet, amelyek a Kataib Hezbollahhal szemben nem tekinthetők iraki állami szervnek.

Végül, de nem utolsósorban szükséges említést tenni arról, hogy az Egyesült Államokat 2019 nyarától 2019 december végéig vélhetően egyáltalán nem érte fegyveres támadás. A fentiekben jellemzett esetek az erőszak alkalmazásának kevésbé súlyos $^{84}$ formái voltak. Az USA által kiemelt egyetlen személy halálát előidéző akció példának okáért önmagában még jó eséllyel nem volt fegyveres támadásnak tekinthető. ${ }^{85}$ Ezen felül az USA-t ért utolsó támadás, amely a bagdadi amerikai nagykövetség ellen zajlott pedig ipso facto képtelen az önvédelmi jog aktiválására, ${ }^{86}$ így függetlenül a támadás intenzitásától és következményeitöl, az USA ennek kapcsán nem hivatkozhatott volna arra, hogy fegyveres támadás érte.

\subsubsection{A MEGELŐZŐ ÖNVÉDELEM}

Mielőtt az Egyesült Államok elküldte volna az 51. cikk szerinti levelét az ENSZ Biztonsági Tanácsának, amelyben múltbeli támadásokra hivatkozott önvédelmi akciója igazolásául, ${ }^{87}$ az amerikai nyilatkozatok más irányba mutattak. A célzott likvidálást követő első megnyilvánulások még egy közelebbről nem részletezett, de jövőbeni iráni fenyegetésről szóltak. Donald Trump az akciót követően egy fehérházi sajtótájékoztatón akként fogalmazott, hogy Szolejmáni tábornok „küszöbön álló és fenyegető támadásokat" ${ }^{88}$ tervezett az Egyesült Államok ellen, ezért volt szükség a likvidálására. Később Mike Pompeo - egykori amerikai külügyminiszter - már úgy

\footnotetext{
${ }^{82}$ Nicaragua ügy para. 115.

${ }^{83}$ Definition of Aggression, G.A. Res. 3314 (XXIX), U.N. Doc. A/RES/3314 (1974) 3. cikk (g) pont.

${ }^{84}$ Nicaragua ügy para. 191.

${ }^{85}$ A Nemzetközi Bíróság számára például egy amerikai tankerhajóra lőtt rakéta nem volt elégséges a fegyveres támadáshoz. Ld. Olajfúrótornyok ügy para. 64. Az Eritrea-Etiópiai Igények Bizottsága szintén úgy foglalt állást, hogy elszigetelt, kisebb gyalogos egységek közötti összeütközések, még akkor sem tekinthetően fegyveres támadásnak, ha azok halálos áldozattal járnak. Ld. EritreaEthiopia Claims Commission - Partial Award: Jus Ad Bellum - Ethiopia’s Claims 1-8. 2005. december 19. 11. bek.

${ }^{86}$ BALÁzs Gergő - KAJTÁR Gábor: „Negyven évvel a teheráni túszdráma után - az önvédelem joga az állami képviseletek elleni támadások esetén” Állam- és Jogtudomány 2020/61. 3-24.

${ }^{87} \mathrm{Az}$ Egyesült Államok 51. cikk szerinti levele.

${ }^{88}$ Lásd: c-span.org/video/?467859-1/president-trump-speaks-air-strike-killed-iranian-commander.
} 
fogalmazott: „[n]em tudjuk pontosan mikor, és nem tudjuk pontosan, hol, de valósak voltak” - utalt az exminiszter a már fent említett „küszöbön álló” fenyegetésekre. ${ }^{89}$ Érdemes még a Pentagon közleményét is idézni, amely szerint „[a] csapás célja elrettenteni Iránt jövőbeli támadások tervezésétől." ${ }^{90}$ Ezek alapján az USA egyfajta megelőző önvédelmi szituációra alapította önvédelmi magatartása jogszerűségét, ugyanakkor tudjuk, hogy később megváltoztatta érvelése logikáját. Mivel a későbbi dokumentumok sem hagyják teljesen figyelmen kívül a jövőbeni támadásokat veszélyét, csupán arra mutatnak rá, hogy a korábbi támadások is lehetővé teszik az önvédelem alkalmazását, ${ }^{91}$ ezért célszerủ ezt az érvelést is górcső alá helyezni, és megvizsgálni, hogy így a jus contra bellum szempontjából jogszerünek fogadható-e el az Egyesült Államok önvédelmi cselekménye.

Az önvédelem jogának alkalmazása során különös figyelmet kell fordítani a fegyveres támadás időbeli dimenziójának is, azaz voltaképpen annak a problémának, hogy be kell-e következnie fegyveres támadásnak az önvédelem alkalmazásához, vagy elegendő lehet az is, ha egy ilyen támadás például csak „küszöbön áll”.

Az ENSZ Alapokmánya viszonylag egyszerủen rendezi a problémát, az ugyanis már a szerződés szövegének nyelvtani értelmezésével kizárja a még be nem következő fegyveres támadás esetén az önvédelem alkalmazását. Erre az angol nyelvű szöveg „if an armed attack occurs”92 kifejezésből következtethetünk. A szerződés előkészítő dokumentumai pedig arra is világosan rámutatnak, hogy a szerződő felek szánt szándékkal zárták ki a megelőző önvédelem lehetőségét. ${ }^{93}$ Tekintve, hogy a nemzetközi szokásjog és a nemzetközi szerződések azonos hierarchikus szinten vannak, így a szinte valamennyi államot érintő ENSZ Alapokmány elfogadása egyfajta lex posterioriként felülírta a korábban meglévő szokásjogi szabályokat. ${ }^{94}$ Ebből az következik, hogy a fegyveres támadás bekövetkezése 1945 után az önvédelem alkalmazásának alapvető követelménye lett. ${ }^{95}$ Az 1945 óta eltelt közel nyolc évtized lényegesen nem változtatott a fenti helyzeten, ${ }^{96}$ ezt azonban kissé árnyalni szükséges.

Ahhoz, hogy a megelőző önvédelem kérdésköréről érdemben szót lehessen ejteni, érdemes néhány szóban körülhatárolni, hogy a különböző fogalmak mit takarnak,

${ }^{89}$ Quint Forgery: „Pompeo insists Soleimani threat was 'imminent' despite blowback” Politico 2020. január 10. politico.com/news/2020/01/10/pompeo-spars-with-reporters-over-imminent-soleimani-threat-097175.

${ }^{90}$ Lásd: defense.gov/Newsroom/Releases/Release/Article/2049534/statement-by-the-departmentof-defense/fbclid/IwAROrmh0P4VvWSUsztiSvRBgyXIZIt5l2GfC15C3m-9g6RADrugC1mNXBiqo/.

91 USA állásfoglalás 2 .

92 ENSZ Alapokmány 51. cikk.

${ }^{93}$ KAJTÁR Gábor: A nem állami szereplők elleni önvédelem a nemzetközi jogban (Budapest: Eötvös Kiadó 2015) 98.

${ }^{94}$ RuYs (56. lj.) 259.

95 Yoram Dinstein: War Agression and Self-Defence. Sixth Edition. (Cambridge: Cambridge University Press 2017) 223., https://doi.org/10.1017/cbo9780511920622.001. Ezzel az állítással természetesen nem mindenki ért egyet, pl. Tibori-Szabó Kinga is azon az állásponton van, hogy az ENSZ Alapokmány nem változtatta meg a korábbi megengedő állami gyakorlatot. Ld. TIBORISzabó Kinga: Anticipatory Action in Self-Defence - Essence and Limits under International Law (Hága: Springer 2011) 283-286., https://doi.org/10.1007/978-90-6704-796-8_13.

${ }^{96}$ Ruys (56. lj.) 341. Tibori-Szabó (95. lj.) 283-284. 
ugyanis ezek sok esetben félreértésre adhatnak okot. ${ }^{97}$ Tom Ruys példának okáért különbséget tesz reaktív (reactive) önvédelem és megelőző (anticipatory) önvédelem között, ahol az elöbbi egy már bekövetkezett vagy folyamatban lévő fegyveres támadásra reagál, utóbbi pedig jövőbeni fenyegetésekre ad választ. A megelőző önvédelem két kategóriára bontható: preemptív önvédelemként a „küszöbön álló" fenyegetésekkel szembeni önvédelemről beszélhetünk, míg preventív önvédelem esetén a még testet nem öltött jövőbeni fenyegetésekkel szemben is védekezhet az állam. A reaktív és a megelőző önvédelem metszéspontjában helyezkedik el a feltartóztató (interceptive) önvédelem, ami akkor alkalmazható, ha egy támadás már megindult, de még nem érte el a védekező államot. ${ }^{98}$

Bár a preventív önvédelmet a nemzetközi jogászok teljes mértékben elutasítják, ${ }^{99} \mathrm{a}$ preemptív, tehát a küszöbön álló támadásokkal szembeni önvédelmet azonban egyre több állam és a nemzetközi jogászok többsége is jogszerủnek fogadja el, annak ellenére, hogy az ENSZ Alapokmány által felvázolt tilalom szokásjogi úton legfeljebb egy olyan szabállyal módosítható, amely eléri a nemzetközi jog feltétlen alkalmazást igénylő szabályának szintjét. Tekintve pedig, hogy ehhez a nemzetközi közösség, mint egész ilyen jogi meggyőződése szükséges, efféle módosulásról Szolejmáni célzott likvidálásáig semmiképpen sem beszélhetünk. ${ }^{100}$

Mindezek ellenére az Egyesült Államok célzott likvidálási programjának gerincét képezi az a jogi meggyőződés, miszerint az Egyesült Államok ugyan „küszöbön álló" fenyegetések ellen alkalmaz önvédelmet, azonban ehhez nem szükséges az, hogy kellő bizonyítékkal rendelkezzen egy, a közeljövőben bekövetkező támadásról. ${ }^{101}$ Ezzel pedig voltaképpen egy preventív önvédelmi policyt alkalmaz, amely már a Bush-kormányzat alatt is komoly negatív visszhangokat váltott ki. ${ }^{102}$

Ez a gyakorlat és különösen a Szolejmáni tábornok elleni célzott likvidálás élesen mutat rá a „küszöbön álló” fenyegetésekre adott önvédelmi akciók parttalanságára. A „küszöbön állóság” ugyanis attól függ, hogy mit értünk alatta, ahogy azt egy amerikai tisztviselő mondta a támadással kapcsolatban. ${ }^{103}$ Mary Ellen O’Connell helyesen mutat rá arra, hogy az államok azért használják a „küszöbön álló” támadá-

97 A fogalmak használatának zavarára mutat rá Craig Martin is. Ld. Craig MARTıN: „Challenging and Refinin the „Unwilling or Unable” Doctrine.” Vanderbilt Journal of Transnational Law 2019. 415416.

98 RuYs (56. lj.) 253.

${ }^{99}$ KAJTÁR Gábor: „Az erőszak tilalma” in JAKAB András - FeKEte Balázs (szerk.): Internetes Jogtudományi Enciklopédia (Nemzetközi jog rovat, rovatszerkesztő: Sulyok Gábor) ijoten.hW szocikk/az-eroszak-tilalma (2018). 54. bek. RuYs (56. lj.) 322.

${ }^{100}$ RuYs (56. lj.) 325. 331-334. 341-342. 1969. évi bécsi egyezmény 53. cikk. Kihirdette: A szerződések jogáról szóló, Bécsben az 1969. évi május hó 23. napján kelt szerződés kihirdetéséről szóló 1987. évi 12. törvényerejű rendelet.

${ }^{101}$ Department of Justice White Paper. Lawfulness of a Lethal Operation Directed Against a U.S. Citizen Who Is a Senior Operational Leader of Al-Qa'ida or An Associated Force. 2011. november 8., 7, justice.gov/sites/default/files/oip/legacy/2014/07/23/dept-white-paper.pdf.

${ }^{102}$ Ruys (56. lj.) 308-309. 321-322.

${ }^{103}$ Mary Ellen O’Connell: „The Illusory Standard of Imminence in the International Law of SelfDefense" SSRN2021. február 16., 3., https://doi.org/10.2139/ssrn.3784820. 
sokkal szembeni önvédelem koncepcióját, mert egy standard alkalmazásának illúzióját kelti, annak ellenére, hogy képtelen az önvédelem alkalmazásának korlátjaként funkcionálni, egészen addig, ameddig azt az államok valós tartalommal, egyfajta standarddal nem töltik meg azt. ${ }^{104}$ A koncepció jelenlegi határozatlansága egyfajta kritikus bizonytalanságot kölcsönöz a doktrínának, ${ }^{105}$ amely álláspontunk szerint egy újabb ékes példája a konstruktív kétértelműség elvének. ${ }^{106}$

Mindezek mellett azonban azt is meg kell jegyezni, hogy Szolejmáni tábornok célzott likvidálása még akkor sem tekinthető bizonyosan jogszerűnek, ha liberálisabban értelmezzük a preemptív önvédelem kérdését, és egy szigorúan véve „küszöbön álló” támadással szemben el is fogadjuk az önvédelem lehetőségét. Agnès Callamard aki e liberálisabb megközelítést alkalmazza - a támadásról készült jelentésében például kiemeli, hogy a támadás céljának leginkább az elrettentés tűnik, tekintve, hogy az USA anélkül likvidálta a tábornokot, hogy konkrétan megnevezte volna azokat az akciókat, amelyek elkövetésére Szolejmáni készült, ugyanis az Egyesült Államok által konkrétan megnevezett incidensek már mind véget értek. ${ }^{107}$ Felvethető mindezekkel kapcsolatban egy további kérdés is. Pusztán Szolejmáni tábornok likvidálása elegendő lett volna arra, hogy az amerikaiak megelőzzék a „küszöbön áll” iráni támadást vagy támadásokat? A válasz minden bizonnyal nem, ugyanis önmagában a tábornok likvidálása vélhetően nem lett volna elég ahhoz, hogy elejét vegyék egy vagy több fegyveres támadásnak. ${ }^{108}$

\section{4. ÖSSZEFOGLALÁS ÉS KÖVETKEZTETÉSEK}

A Szolejmáni tábornok elleni célzott likvidálási akció jelentőségét nem lehet eléggé hangsúlyozni. A művelet egyfelől éles váltást jelentett az Egyesült Államok gyakorlatában, amely hosszú ideje először alkalmazott újra célzott erőszakot egy másik állam katonai vezetőjével szemben, a korábbi, nem terrorista vagy terrorista gyanús személyek elleni akciók helyett, amelyek így nem állami szereplőkhöz kapcsolódtak. Másfelől azonban a „hagyományos”, nem állami szereplőkhöz köthető célzott likvidálásokhoz hasonlóan ez a mủvelet sem volt képes megbirkózni az ilyen akciók típushibáival, így nemzetközi jogi értelemben ez az akció is jogellenesnek minősül, legalábbis ami a jus contra bellum szabályainak betartását illeti.

A nemzetközi közösség jelentős része, mint szinte minden hasonló esetben - ha egyáltalán véleményt nyilvánított a kérdésben - semleges álláspontot foglalt el. Ez saját kategorizálásunk szerint harminchat államot és nemzetközi szervezetet jelen-

${ }^{104}$ Uo. 9. 37.

${ }^{105}$ Uo. 39.

${ }^{106}$ Dapo Akande - Marko Milanovic: „The Constructive Ambiguity of the Security Council's ISIS Resolution.” EJIL:Talk! 2015. november 21. ejiltalk.org/the-constructive-ambiguity-of-thesecurity-councils-isis-resolution.

${ }^{107} \mathrm{~A} / \mathrm{HRC} / 44 / 38$ 61. 76. bek.

${ }^{108}$ Marc Polymeropoulos: „How to Think About the Soleimani Strike in Four Questions” Just Security 2020. január 17. justsecurity.org/68094/how-to-think-about-the-soleimani-strike-in-four-questions. 
tett az akció kapcsán, amik főként az eszkaláció veszélyére hívták fel a figyelmet. A nyolc támogató és tizenegy elítélő nyilatkozat pedig nem képes egyértelmủen és világosan jelezni az államok pozícióját a támadás jogi megítélését illetően.

Szoljemáni tábornok célzott likvidálására az Egyesült Államok önvédelmi jogának gyakorlása keretében került sor, ugyanakkor az USA nem akart és nem is tudott egy olyan konkrét fegyveres támadást megnevezni, amely egyértelműen jogot adott volna számára az Irán elleni önvédelmi cselekmény alkalmazására. Ehelyett az Egyesült Államok elsőként a megelőző önvédelem tartalmában végső soron preventív változatára hivatkozott, amelyben a Szolejmáni tábornok által tervezett támadások helye és ideje sem volt ismert. A tanulmányban rámutattunk, hogy bár az USA célzott likvidálási programja részeként már hosszú évek óta ezt a koncepciót követi, a nemzetközi közösség és a nemzetközi jogászok elsöprő többsége nem tartja jogszerünek az ilyen katonai műveleteket.

Talán a jogellenesség vádjának elkerülése érdekében, talán más okból az Egyesült Államok a Biztonsági Tanácsnak küldött levelében már egy másik elvet, az események összeadódásának elvét követte. Az elmélet lényege abban áll, hogy az USA-t ért támadások összeadódva egy „nagy” fegyveres támadásnak tekinthetők, amelyek esetében így jogszerü lesz az önvédelem. A válaszcsapás szükségességét azonban itt is egy meg nem határozott, jövőbeni újabb támadás visszaverése adja. Bár az esettanulmányban akként foglaltunk állást, hogy az ilyen és ehhez hasonló szituációk fegyveres támadásként való elfogadása nem jelent lényeges különbséget a megelőző önvédelemhez képest, amelyet pedig a távoli fenyegetések esetén semmiképpen, a „küszöbön álló” fenyegetésekkel szemben pedig a koncepció tartalmatlansága, „standard” jellegének hiányából adódóan nem fogadhatunk el megfelelőnek. Ezt az álláspontot annak ellenére fenntartjuk, hogy a Nemzetközi Bíróság és az állami gyakorlat is támogatni látszik az ilyen, összeadódási alapú önvédelmet, továbbá az Egyesült Államok továbbra is erre alapozza célzott támadásait a régióban. ${ }^{109} \mathrm{Az}$ önvédelem jogának ilyen mértékủ kitágítása véleményünk szerint súlyosan veszélyeztetné a jus ad bellum közel nyolcvan éve állandó rendszerét, amelyben kizárólag a már bekövetkezett, vagy éppen folyamatban lévő fegyveres támadásokra lehet szintén erőszak alkalmazásával reagálni.

A fentiekből adódóan tehát az Egyesült Államok nem volt fegyveres támadás áldozata, így önvédelmi akciója ipso facto jogellenesnek tekinthető, az önvédelem gyakorlásának szükségességi és arányossági vizsgálata pedig ebből következően szükségtelen.

${ }^{109}$ Letter dated 29 June 2021 from the Permanent Representative of the United States of America to the United Nations addressed to the President of the Security Council, 30 June 2021. U.N. Doc. S/2021/614. A levélben folyamatban lévő és eszkalálódó támadásokról esik szó. 


\section{1. sz. táblázat}

Elítélő állami nyilatkozatok

\begin{tabular}{|c|c|}
\hline ÁLLAM & A NYILATKOZAT LÉNYEGES TARTALMA \\
\hline Irán & $\begin{array}{l}\text { Nyilvánvaló módon a leghevesebb tiltakozást Iránban váltotta ki a Szolejmáni elle- } \\
\text { ni támadás, ahol az államfö „állami terrorizmusnak” és bűncselekménynek nevezte } \\
\text { a támadást, és többször is heves és komoly válaszcsapást helyezett kilátásba. }{ }^{110}\end{array}$ \\
\hline Irak & $\begin{array}{l}\text { Az iraki kormány az ENSZ Biztonsági Tanácsának küldött levelében elítélte a } \\
\text { támadást. A levélben megemlítik, hogy provokatívnak és ellenségesnek tekin- } \\
\text { tik azokat a katonai akciókat, amelyeket engedély nélkül hajtanak végre a terüle- } \\
\text { tükön.111 }\end{array}$ \\
\hline Kína & $\begin{array}{l}\text { A kínai külügyi szóvivő úgy nyilatkozott, hogy a megtörtént akciók ellentéte- } \\
\text { sek a nemzetközi joggal, és felszólította a különböző államokat - de különösen az } \\
\text { Egyesült Államokat - a visszafogottságra. }{ }^{112}\end{array}$ \\
\hline Oroszország & $\begin{array}{l}\text { Az orosz külügyminiszter - egyebek mellett - amerikai kollégájával is telefonbe- } \\
\text { szélgetést folytatott az események miatt, amelyben a nemzetközi jog durva meg- } \\
\text { sértésének nevezte az ilyen akciókat. }{ }^{113}\end{array}$ \\
\hline Kuba & $\begin{array}{l}\text { A kubai külügyminiszter Twitter-bejegyzésben ítélte el határozottan a Szolejmáni } \\
\text { tábornokot ért dróncsapást. }{ }^{14}\end{array}$ \\
\hline Malajzia & $\begin{array}{l}\text { A maláj miniszterelnök Dzsamál Hasogdzsi meggyilkolásához hasonlította a } \\
\text { Szolejmáni elleni akciót, mindkettőt erkölcstelennek és jogtalannak nevezte. }{ }^{115}\end{array}$ \\
\hline Szíria & $\begin{array}{l}\text { A szír külügyminiszter „áruló, bűnözői amerikai agresszió”-ról beszélt a támadás } \\
\text { kapcsán, és „teljes szolidalitásáról” biztosította az iráni kormányt. }{ }^{116}\end{array}$ \\
\hline Venezuela & $\begin{array}{l}\text { A venezuelai külügyminisztérium közleményében határozottan elítélte az amerikai } \\
\text { akciót, és Szíriához hasonlóan szolidaritásukról biztosították Iránt. }{ }^{117}\end{array}$ \\
\hline Törökország & $\begin{array}{l}\text { Erdogan elnök egy héttel egy törtök külügyminisztériumi közleményt követően } \\
\text { Putyin elnökkel tett közös nyilatkozatában fejezete ki aggodalmát a támadás kap- } \\
\text { csán, és kijelentették, hogy az amerikai támadást a békét és biztonságot aláásó } \\
\text { cselekményként értékelik. }{ }^{118}\end{array}$ \\
\hline Szlovénia & $\begin{array}{l}\text { A külügyminisztérium egy rövid közleményben ítélte el az Irakban lezajlott erő- } \\
\text { szakos cselekményeket. }{ }^{19}\end{array}$ \\
\hline Libanon & $\begin{array}{l}\text { A libanoni külügyminisztérium rövid közleményben említi meg, hogy a táma- } \\
\text { dás sérti Irak szuverenitását és a támadás egy veszélyes eszkaláció Iránnal szem- } \\
\text { ben. }{ }^{120}\end{array}$ \\
\hline
\end{tabular}

${ }^{110}$ Forrás: https://www.tehrantimes.com/news/462681/Ambassador-Gen-Soleimani-assassinationwas-clear-example-of; https://en.mfa.ir/portaVnewsview/570647.

${ }^{111}$ Forrás: https://undocs.org/S/2020/15.

${ }^{112}$ Forrás: https://www.fmprc.gov.cn/mfa_eng/xwfw_665399/s2510_665401/2511_665403/ t1729508.shtml.

${ }^{113}$ Forrás: https://www.mid.rw/en/foreign_policy/news/-/asset_publisher/cKNonkJE02Bw/content/id/3989636.

${ }^{114}$ Forrás: https://twitter.com/BrunoRguezP/status/1213246491780886529.

${ }^{115}$ Forrás: https://www.aa.com.tr/en/asia-pacific/-soleimani-killing-illegal-immoral-malaysianpremier/1695288.

${ }^{116}$ Forrás: https://www.justsecurity.org/68173/compilation-of-states-reactions-to-u-s-and-iranian-uses-of-force-in-iraq-in-january-2020/\#ReactionsIllegalUSStrike.

${ }^{117}$ Forrás: http://www.mppre.gob.ve/en/comunicado/venezuela-condemns-us-military-attack-inthe-republic-of-irad.

${ }^{118}$ Forrás: https://undocs.org/S/2020/31.

${ }^{119}$ Forrás: https://www.gov.si/en/news/2020-01-03-mfa-on-the-situation-in-iraq.

${ }^{120}$ Forrás: https://www.reuters.com/article/us-iraq-security-blast-lebanon/lebanon-condemns-soleimani-killing-hopes-for-no-repercussions-idUSKBN1Z218R. 


\section{2. sz. táblázat}

Semleges állami és nemzetközi szervezeti nyilatkozatok

\begin{tabular}{|c|c|}
\hline $\begin{array}{l}\text { ÁLLAM/ } \\
\text { NEMZETKÖZI } \\
\text { SZERVEZET }\end{array}$ & A NYILATKOZAT LÉNYEGES TARTALMA \\
\hline Európai Unió & $\begin{array}{l}\text { „Az erőszak, a provokációk és a megtorlások ciklusát, amelynek tanúi lehetünk } \\
\text { Irakban, meg kell állítani." } 121\end{array}$ \\
\hline ENSZ & Antonio Guterres maximális visszafogottságot kért a felektől. ${ }^{122}$ \\
\hline NATO & A NATO is az eszkaláció csökkentésére hívta fel a feleket. ${ }^{123}$ \\
\hline India & $\begin{array}{l}\text { Az indiai külügyminisztérium közleményében megjegyzi, hogy a régió stabilitá- } \\
\text { sa fontos számára. „Létfontosságú, hogy a helyzet ne eszkalálódjon tovább” - áll a } \\
\text { közleményben. }{ }^{124}\end{array}$ \\
\hline $\begin{array}{l}\text { Franciaország } \\
\text { - Németország } \\
\text { - Egyesült } \\
\text { Királyság }\end{array}$ & $\begin{array}{l}\text { A három állam közös nyilatkozatban hívta fel a feleket az eszkaláció csökkentésé- } \\
\text { re. A nyugati államok önállóan is tettek nyilatkozatokat a támadás kapcsán, azon- } \\
\text { ban a semleges nézőponttól egyik állam sem szakadt el. }{ }^{125}\end{array}$ \\
\hline Argentína & $\begin{array}{l}\text { Az argentin közleményben többek között azt kérik az Egyesült Államoktól és } \\
\text { Irántól, hogy közösen dolgozzanak az eset megoldásán. }{ }^{126}\end{array}$ \\
\hline Ausztrália & $\begin{array}{l}\text { „[...] amire törekszünk, az a visszafogottság, a deeszkaláció, és a folyamatos kap- } \\
\text { csolattartás a partnereinkkel a kérdés kapcsán...” }\end{array}$ \\
\hline Bahrein & $\begin{array}{l}\text { "Az erőszak, a szélsőségesség, valamint a terrorizmus minden formáját kezelni } \\
\text { kell” - áll a külügyminisztérium közleményében. }{ }^{128}\end{array}$ \\
\hline Bulgária & $\begin{array}{l}\text { A bulgáriai külügy Twitter-bejegyzésben adott hangot aggodalmának az eset kap- } \\
\text { csán. }{ }^{129}\end{array}$ \\
\hline Kanada & $\begin{array}{l}\text { A kanadai közlemény a legtöbb állásfoglaláshoz hasonlóan az erőszak visszafo- } \\
\text { gására hívta fel a feleket, ugyanakkor megjegyzik, hogy régóta aggasztotta őket } \\
\text { Szolejmáni tábornok tevékenysége. }{ }^{130}\end{array}$ \\
\hline Észtország & $\begin{array}{l}\text { Az észt külügyminisztérium - több más államhoz hasonlóan - Twitter-fiókján } \\
\text { keresztül fejezte ki aggodalmát, és diplomáciai megoldásra biztatta a feleket. }{ }^{131}\end{array}$ \\
\hline
\end{tabular}

${ }^{121}$ Forrás: https://www.consilium.europa.ew/en/press/press-releases/2020/01/03/statement-bycharles-michel-president-of-the-european-council-on-the-situation-in-iraq ?fbclid=IwAR3DufOyW08HMAhNKzTuEDYglKdLtftQpexdDM59lDjLEEVbl4QKbRmJu3o.

${ }^{122}$ Forrás: https://news.un.org/en/story/2020/01/1054701.

${ }^{123}$ Forrás: https://www.nato.int/cps/en/natohq/opinions_172346.htm? selectedLocale=en.

${ }^{124}$ Forrás: https://mea.gov.in press-releases.htm?dtl\%2F32251\%2FKilling_of_a_senior_Iranian_leader_by_the_US\&fbclid=IwAR3kLVNK9Y9_L7TjGYxL72O7ov2c1OwCiwZC3q_nuM6fS2ft1cWtfmg $8 \mathrm{Hs}$.

${ }^{125}$ Forrás: http://basedoc.diplomatie.gouv.fr/vues/Kiosque/FranceDiplomatie/kiosque.php?fichier=baen2020-01-06.html\& fbclid=IwAR31 ACVOoIg8vFfBt7S6uScbav19iaK0GOT_ I9X03yW17bZF5wBpOro60t0\#Chapitre2.

${ }^{126}$ Forrás: https://www.cancilleria.gob.ar/en/announcements/news/press-release-2.

${ }^{127}$ Forrás: https://www.pm.gov.au/media/press-conference-australian-parliament-house.

${ }^{128}$ Forrás: https://www.mofa.gov.bh/Default.aspx?tabid=7824\&language =en-US\&ItemId=12202.

${ }^{129}$ Forrás: https://twitter.com/MFABulgaria/status/1213428390507765760.

${ }^{130}$ Forrás: https://www.canada.ca/en/global-affairs/news/2020/01/statement-from-minister-champagne.html.

${ }^{131}$ Forrás: https://twitter.com/GudlaugurThor/status/1213201100226138118? s=20. 


\begin{tabular}{|c|c|}
\hline Fülöp-szigetek & $\begin{array}{l}\text { A Fülöp-szigetek elnöki hivatalának szóvivője egy sajtótájékoztató keretében } \\
\text { akként nyilatkozott, hogy a legfontosabb a Fülöp-szigetek állampolgárainak biz- } \\
\text { tonsága, de az erőszak alkalmazásának legalitása kapcsán nem kívánt állást fog- } \\
\text { lalni. }{ }^{132}\end{array}$ \\
\hline Katar & $\begin{array}{l}\text { A katari külügyminisztérium rövid közleményében valamennyi felet visszafogott- } \\
\text { ságra és az eszkaláció megállapítására szólította fel. }{ }^{133}\end{array}$ \\
\hline Örményország & $\begin{array}{l}\text { Örményország aggodalmát fejezte ki, hogy az események aláássák a regionális } \\
\text { biztonságot, és destabilizálják a régiót és a világot. }{ }^{134}\end{array}$ \\
\hline Szaúd-Arábia & $\begin{array}{l}\text { A szaúdi külügyminisztérium Twitter-bejegyzésben szólította fel a feleket az } \\
\text { „önmegtartóztatás fontosságára”. }{ }^{135}\end{array}$ \\
\hline Azerbajdzsán & $\begin{array}{l}\text { Az azeri külügyminiszter felszólította a feleket, hogy kötelezzék el magukat a } \\
\text { közel-keleti régió biztonsága mellett, ugyanakkor a miniszter „mély részvétét” } \\
\text { fejezte ki Iránnak a tábornok halála miatt. }{ }^{136}\end{array}$ \\
\hline Egyiptom & $\begin{array}{l}\text { Egyiptom aggodalmát fejezte ki az események miatt, és a közleményben megem- } \\
\text { lítik, hogy úgy vélik, az összes beavatkozást azonnal meg kellene szüntetni a tér- } \\
\text { ségben a különböző államok részéröl. }{ }^{137}\end{array}$ \\
\hline Luxemburg & Luxemburg diplomáciai megoldást javasolt a felek számára. ${ }^{138}$ \\
\hline Ukrajna & $\begin{array}{l}\text { Ukrajna aggodalmát fejezte ki az események kapcsán, ugyanakkor közleményében } \\
\text { főleg az iráni akciókról számolt be. }{ }^{139}\end{array}$ \\
\hline Fehéroroszország & $\begin{array}{l}\text { A fehérorosz külügyminiszter elítélte a különböző diplomáciai képviseletek elleni } \\
\text { támadásokat, és mindkét felet a deeszkaláció elősegítésére hívta fel. }{ }^{10}\end{array}$ \\
\hline Belgium & $\begin{array}{l}\text { A belga külügyminiszter Twitter-bejegyzésben fejezte ki az aggodalmát az ese- } \\
\text { mények kapcsán. }{ }^{141}\end{array}$ \\
\hline Görögország & $\begin{array}{l}\text { Görögország is aggodalmát fejezte ki a történtek miatt, majd „józanságra és nyu- } \\
\text { galomra” hívta fel a feleket a helyzet megoldása érdekében. }{ }^{42}\end{array}$ \\
\hline Indonézia & $\begin{array}{l}\text { „Felszólítjuk a feleket, hogy tartózkodjanak minden olyan cselekményektől, ame- } \\
\text { lyek tovább súlyosbíthatják a helyzetet." }\end{array}$ \\
\hline
\end{tabular}

${ }^{132}$ Forrás: https://pcoo.gov.ph/press-briefing/press-briefing-of-presidential-spokesperson-and-chief-presidential-legal-counsel-secretary-salvador-panelo-139/.

${ }^{133}$ Forrás: https://www.mofa.gov.qa/en/statements/qatar-warns-of-continuation-of-escalationmanifestations-in-iraq-urges-restraint.

${ }^{134}$ Forrás: https://www.mfa.am/en/interviews-articles-and-comments/2020/01/03/statement_ Baghdad/10027.

${ }^{135}$ Forrás: https://twitter.com/KSAmofaEN/status/1213136791966027776? s=20.

${ }^{136}$ Forrás: https://www.justsecurity.org/68173/compilation-of-states-reactions-to-u-s-and-iranian-uses-of-force-in-iraq-in-january-2020\%.

${ }^{137}$ Forrás: https://www.justsecurity.org/68173/compilation-of-states-reactions-to-u-s-and-iranian-uses-of-force-in-iraq-in-january-2020\%.

${ }^{138}$ Forrás: https://maee.gouvernement.lw/fr/actualites.gouvernement\%2Bfr\%2Bactualites\%2Btoutes_actualites\%2Bcommuniques\%2B2020\%2B01-janvier\%2B03-asselborn-irak.html.

${ }^{139}$ Forrás: https://mfa.gov.ua/en/news/76844-zajava-mzs-ukrajini-shhodo-jeskalaciji-situacijina-blizykomu-skhodi.

${ }^{140}$ Forrás: https://www.justsecurity.org/68173/compilation-of-states-reactions-to-u-s-and-iranian-uses-of-force-in-iraq-in-january-2020\%.

${ }^{141}$ Forrás: https://twitter.com/PhGoffin/status/1213092011747823616.

${ }^{142}$ Forrás: https://www.mfa.gr/en/current-affairs/statements-speeches/ministry-of-foreign-affairs-statement-on-the-developments-in-iraq-january-2020.html.

${ }^{143}$ Forrás: https://kemlu.go.id/portaVen/read/940/berita/pernyataan-mengenai-eskalasi-situasidi-irak. 


\begin{tabular}{|c|c|}
\hline Olaszország & $\begin{array}{l}\text { Az olasz külügyminisztérium veszélyes eszkalációnak nevezte az eseményeket, } \\
\text { amelynek a csúcspontja Szolejmáni tábornok likvidálása volt, emellett „mértékle- } \\
\text { tességre” szólította fel a feleket. }{ }^{144}\end{array}$ \\
\hline Japán & $\begin{array}{l}\text { Japán diplomáciai erőfeszítésekre szólította fel a feleket a helyzet rendezése érde- } \\
\text { kében. }{ }^{145}\end{array}$ \\
\hline Mexikó & $\begin{array}{l}\text { A mexikói külügyminisztérium Twitter-bejegyzésben a párbeszéd és a tárgyalá- } \\
\text { sok mellett érvelt a helyzet megoldására vonatkozóan. }{ }^{146}\end{array}$ \\
\hline Szingapúr & $\begin{array}{l}\text { Szingapúr „mélységes aggodalmát” fejezte ki a közel-keleti események kapcsán, } \\
\text { és maximális visszafogottságot kért a felektől. }{ }^{147}\end{array}$ \\
\hline Svédország & $\begin{array}{l}\text { A svéd külügyminisztérium szerint a helyzet eszkalációja súlyos aggodalomra ad } \\
\text { okot. „Mindkét félnek visszafogottnak kell lennie” - áll továbbá a közleményben. }{ }^{148}\end{array}$ \\
\hline $\begin{array}{l}\text { Egyesült Arab } \\
\text { Emírségek }\end{array}$ & $\begin{array}{l}\text { „A bölcsességnek, egyensúlynak, és a politikai megoldásoknak kell érvényesülnie } \\
\text { a konfrontációval és eszkalációval szemben..." }{ }^{449}\end{array}$ \\
\hline Pakisztán & $\begin{array}{l}\text { A pakisztáni külügyminisztérium szóvivője bejegyzésben megemlíti, hogy mély } \\
\text { aggodalommal figyelik az eseményeket, és a nemzetközi jog, különösen az ENSZ } \\
\text { Alapokmány betartását kérte a felektől. }{ }^{150}\end{array}$ \\
\hline $\begin{array}{l}\text { Dél-afrikai } \\
\text { Köztársaság }\end{array}$ & $\begin{array}{l}\text { A közleményből az tűnik ki, hogy a kormányt aggasztja a fokozódó helyzet, és } \\
\text { korábbi nyilatkozatikra utalva kérik az erőszak befejezését és Irak függetlenségé- } \\
\text { nek tiszteletben tartását. }\end{array}$ \\
\hline $\begin{array}{l}\text { Arab Államok } \\
\text { Ligája }\end{array}$ & $\begin{array}{l}\text { Az Arab Liga főtitkára a támadást követően aggodalmát fejezte ki az események } \\
\text { miatt, és akként vélekedett, hogy a régiónak nyugalomra van szüksége. }{ }^{152}\end{array}$ \\
\hline Afganisztán & $\begin{array}{l}\text { Az afgán elnök Twitter-bejegyzésben szólította fel a szemben álló feleket arra, } \\
\text { hogy vitájukat párbeszéd útján oldják meg. }{ }^{153}\end{array}$ \\
\hline $\begin{array}{l}\text { Öböl Menti } \\
\text { Együttműködési } \\
\text { Tanács }\end{array}$ & $\begin{array}{l}\text { A szervezet vezetője aggodalmát fejezte ki, és felszólította az érintetteket, hogy a } \\
\text { politikai megoldásokat helyezzék előtérbe. }{ }^{154}\end{array}$ \\
\hline Panama & $\begin{array}{l}\text { Az egyik panamai kormánytag többször is kiemelte nyilatkozatában, hogy } \\
\text { Panamának meg kell őriznie függetlenségét. }{ }^{155}\end{array}$ \\
\hline Románia & $\begin{array}{l}\text { A román külügyminisztérium Twitter-bejegyzésben szintén a deeszkalációra szó- } \\
\text { lított fel, azzal, hogy elítélte a bagdadi nagykövetség elleni támadást. }{ }^{156}\end{array}$ \\
\hline
\end{tabular}

${ }^{144}$ Forrás: https://www.esteri.it/mae/en/sala_stampa/archivionotizie/comunicati/2020/01/sviluppi-della-situazione-in-iraq.html.

${ }^{145}$ Forrás: https://www.justsecurity.org/68173/compilation-of-states-reactions-to-u-s-and-iranian-uses-of-force-in-iraq-in-january-2020\%.

${ }^{146}$ Forrás: https://www.justsecurity.org/68173/compilation-of-states-reactions-to-u-s-and-iranian-uses-of-force-in-iraq-in-january-2020\%.

${ }^{147}$ Forrás: https://www.mfa.gov.sg/Newsroom/Press-Statements-Transcripts-andPhotos/2020/01/080120_Middle-East-and-Iran-Travel-Advisory.

${ }^{148}$ Forrás: https://twitter.com/AnnLinde/status/1213098802871250949.

${ }^{149}$ Forrás: https://www.justsecurity.org/68173/compilation-of-states-reactions-to-u-s-and-iranian-uses-of-force-in-iraq-in-january-2020\%.

${ }^{150}$ Forrás: https://twitter.com/ForeignOfficePk/status/1213071481086840832.

${ }^{151}$ Forrás: http://www.dirco.gov.za/docs/2020/iran0111.htm.

${ }^{152}$ Forrás: https://www.justsecurity.org/68173/compilation-of-states-reactions-to-u-s-and-iranian-uses-of-force-in-iraq-in-january-2020/\#ReactionsAmbiguousUSStrike.

${ }^{153}$ Forrás: https://www.justsecurity.org/68173/compilation-of-states-reactions-to- $u$-s-and-iranian-uses-of-force-in-iraq-in-january-2020/\#ReactionstoUSStrike.

${ }^{154}$ Forrás: https://twitter.com/ashrafghani/status/1213139843154350086.

${ }^{155}$ Forrás: https://www.gcc-sg.org/en-us/MediaCenter/NewsCooperation/News/Pages/news20201-5-4.aspx.

${ }^{156}$ Forrás: https://twitter.com/MAERomania/status/1213411352657715201. 


\section{3. sz. táblázat}

Támogató állami nyilatkozatok

\begin{tabular}{|c|c|}
\hline$\overline{A ́ L L A M}$ & A NYILATKOZAT LÉNYEGES TARTALMA \\
\hline Egyesült Államok & $\begin{array}{l}\text { Az Egyesült Államok természetesen jogilag alátámaszthatónak tartotta a célzott } \\
\text { likvidálást. }{ }^{157}\end{array}$ \\
\hline Brazília & $\begin{array}{l}\text { A brazil közlemény megjegyzi, hogy Brazília kész támogatni az Egyesült } \\
\text { Államokat a terrorizmus elleni harcban. A nyilatkozat hatására a teheráni brazil } \\
\text { nagykövetet bekérették. }{ }^{158}\end{array}$ \\
\hline Grúzia & „Az Egyesült Államoknak megvan a joga arra, hogy megvédje állampolgárait.”159 \\
\hline Koszovó & $\begin{array}{l}\text { Koszovóban a támadást követően letartóztattak egy Iránt támogató kommente- } \\
\text { lőt, amiért bosszúval fenyegette az Egyesült Államokat. Ezt követően biztosítot- } \\
\text { ta a koszovói miniszterelnök támogatásáról az Egyesült Államokat az önvédelem } \\
\text { joga tekintetében. }{ }^{160}\end{array}$ \\
\hline Litvánia & $\begin{array}{l}\text { „Ahogy bármelyik másik országnak, úgy az USA-nak is megvan a joga védekező } \\
\text { lépésekre, ha a polgárait közvetlenül fenyegetik." }\end{array}$ \\
\hline Lettország & $\begin{array}{l}\text { „Szolidaritást vállalunk szövetségesünkkel, az Egyesült Államokkal az önvédelem } \\
\text { jogának gyakorla tekintetében." }\end{array}$ \\
\hline Albánia & $\begin{array}{l}\text { Az albán külügyminiszter is Twitter-bejegyzésben fejezte ki támogatását az } \\
\text { Egyesült Âllamok irányában. Szolejmáni tábornokot pedig erőszakos szélsőséges- } \\
\text { nek nevezte. }{ }^{163}\end{array}$ \\
\hline Izrael & $\begin{array}{l}\text { Netanjahu miniszterelnök Trump elnököt méltatta az akciót követően, és támo- } \\
\text { gatásáról biztosította az Egyesült Államokat. Kiemelte, hogy csakúgy, mint } \\
\text { Izraelnek, az Egyesült Államoknak is van önvédelmi joga. }{ }^{164}\end{array}$ \\
\hline
\end{tabular}

${ }^{157}$ Forrás: https://www.justsecurity.org/wp-content/uploads/2020/01/united-states-article-51-letter-soleimani.pdf.

${ }^{158}$ Forrás: https://www.reuters.com/article/us-iraq-security-iran-braziViran-summons-brazilscharge-daffaires-in-tehran-after-soleimani-comments-idUSKBN1Z61IF?feedType=RSS\&.

${ }^{159}$ Forrás: https://twitter.com/DZalkaliani/status/1213190674151071749? $s=20$.

${ }^{160}$ Forrás: https://www.reuters.com/article/us-kosovo-iran-crime/kosovo-arrests-iran-supporterover-comments-after-soleimanis-death-idUSKBN1Z62AH.

${ }^{161}$ Forrás: https://twitter.com/LinkeviciusL/status/1213125016465891328.

${ }^{162}$ Forrás: https://twitter.com/edgarsrinkevics/status/1213161574061551626.

${ }^{163}$ Forrás: https://twitter.com/CakajGent/status/1213107908151513088.

${ }^{164}$ Forrás: https://www.justsecurity.org/68173/compilation-of-states-reactions-to-u-s-and-iranian-uses-of-force-in-iraq-in-january-2020/\#ReactionstoUSStrike. 